\title{
EPISCOPOLOGIO MEDIEVAL CORDOBÉS. SIGLOS XIII-XIV
}

\author{
POR \\ ILUMINADO SANZ SANCHO \\ Universidad Autónoma de Madrid
}

\section{RESUMEN}

A pesar de la importancia de la diócesis de Córdoba en la Baja Edad Media, aún no se ha hecho un estudio pormenorizado de sus obispos. Presentamos aquí el episcopologio de los siglos XIII-XIV, confeccionado de manera convencional, pero imprescindible, mientras esperamos concluir otros estudios más amplios y metodológicamente más actualizados acerca de estos obispos cordobeses.

PalABRAS ClAVE: Obispos, Córdoba, Edad Media.

\section{Abstract}

In spite of the importance of the diocese of Córdoba in the Later Middle Ages, an itemized study of its bishops has not still been made. We present the episcopal biographies of the XIII-XIV centuries here, made in a conventional, but indispensable way, while we hope to conclude other wider and metodologycally more upgraded studies about these Cordovan bishops.

KEY WORDS: Bishops, Córdoba, Middle Ages.

A pesar de la importancia de la sede cordobesa y de la producción literaria de los autores tradicionales e incluso algunos actuales, el episcopologio de la Iglesia de Córdoba sigue estando por hacer ${ }^{1}$. La principal dificultad para su

1 J. Gómez BRavo, Catálogo de los obispos de Córdoba y breve noticia histórica de su Iglesia catedral y Obispado. 2 vols. Córdoba, 1778. R. RAMíreZ DE ARELLANO, Historia de Córdoba desde su fundación hasta la muerte de Isabel la Católica. 4 vols. Ciudad Real, 1919. M. NIETO CUMPLIDO,

Episcopado Hispano Hispania Sacra 54 (2002) 
ejecución resulta de que la documentación, que se conservaba en el palacio episcopal, desapareció en un incendio del siglo XVIII, por lo que en adelante se hubo de depender de la información no directa, que mayoritariamente proporciona el Archivo y la Biblioteca de la Catedral de Córdoba.

En consecuencia, las páginas siguientes se dedicarán a reunir y coordinar las noticias dispersas, que han podido encontrarse sobre cada obispo del período medieval, siguiendo el clásico orden cronológico. Aquí sólo recogemos las noticias relevantes que caracterizan a cada obispo. Dejamos para otro lugar un estudio sistemático de la figura eclesial y social de los obispos cordobeses.

\section{LOS OBISPOS DEL SIGLO XIII}

\section{Don LOPE DE Fitero (9 de mayo de 1237 a 10 de junio de 1245).}

La mayoría de los autores, siguiendo el buen criterio de Gómez Bravo², hacen provenir de Burgos al primer obispo de la resturada sede cordobesa. La Primera Crónica General dice de nuestro obispo que era «maestre Lope de Fitero de Río Pisuerga», seguramente la actual población de Itero del Castillo, junto al Pisuerga, en Palencia ${ }^{3}$. Parece lo más probable, dada la numerosa presencia de burgaleses en la Córdoba recién conquistada y poblada, que aparece en la documentación. Numerosos hidalgos, caballeros, peones y artesanos vinieron con sus familias e instituciones a Córdoba, incluidos los clérigos y las devociones, como fue el caso de los monjes de San Pedro de Gumiel, del Hospital de Burgos o de la dedicación de una parroquia y collación de la ciudad a Santo Domingo de Silos.

El maestro don Lope, capellán del rey Fernando III, a quien acompañó en el ejército real a la conquista de Córdoba y procedió al lado del obispo de Osma a la purificación de la gran mezquita y a su dedicación al culto cristiano, parece

Historia de la Iglesia en Córdoba. Reconquista y Restauración (1146-1326). Córdoba, 1991. Otros autores han tratado con mayor o menor profundidad esta temática o parte de ella, pero son menos seguros en sus noticias que los ya citados, entre los que cabe destacar A. MORENO MARTÍN, Antigüedades y grandezas de la catedral de Córdoba. Real Academia de la Historia (=R.A.H.), Ms. 9/3.410. Para la mejor comprensión de los momentos iniciales de la Iglesia en Córdoba durante la Baja Edad Media, puede verse. NiETO CUMPLIDO, M.: Historia de la Iglesia, pp. 33-76. I. SANZ SANCHO, La Iglesia y el Obispado de Córdoba en la Baja Edad Media (1236-1426). 2 vols. Madrid, 1989. I, pp. 71-98.

2 J. GÓMEZ BRAVO, Catálogo.I, p. 258. En adelante no pondremos en nota las abundantes citas a este autor, a no ser estrictamente necesario, pues son fáciles de comprobar.

${ }^{3}$ Primera Crónica General de España, edic. de R. Menéndez Pidal. Madrid, 1977, p. 734.

Episcopado Hispano

Hispania Sacra 54 (2002) 
que debe incluirse entre ese número de burgaleses. El mismo día en el que Eubel afirma que estaba electo obispo de Córdoba, 9 de mayo de 1237, lo vemos en Burgos al servicio del rey, en la sentencia que éste emitió en el pleito, que mantenían los monasterios de Covarrubias y de Cardeña ${ }^{4}$.

Parece lógico que, después de la conquista de Córdoba en 1236 y pensando el rey en ofrecerle el episcopado de la diócesis restaurada, volviera a su lugar de origen, para preparar con sus gentes la vuelta y el establecimiento definitivo. Lo efectuaría al menos con su sobrino, el canónigo y después maestrescuela y arcediano de Córdoba, Martín de Fitero, con su capellán, don Fernando, y con sus familiares. Por lo demás, se conoce a un tal Martín Ruiz «el del obispo» y a un Gonzalo Pérez de Fitero, que confirmarían más esta hipótesis ${ }^{5}$.

Quizá la provisión del obispado recientemente restaurado se hiciera por el arzobispo de Toledo don Rodrigo Jiménez de Rada, quien ya poseía una bula del papa Gregorio IX para promover al episcopado a hombres idóneos en las ciudades de su provincia eclesiástica que anteriormente hubieran sido sedes episcopales y en el presente tales ciudades lo merecieren ${ }^{6}$. Lo cual debió hacerse mediante la presentación de su candidatura por Fernando III, ya que no sólo era su capellán, sino que era letrado al servicio del rey y que, como tal, actuará incluso poco antes de su muerte, siendo juez en el pleito, que por Manzanares y Colmenar Viejo mantenían los concejos de Segovia y de Madrid ${ }^{7}$.

Igualmente ha de pensarse, que fuera el arzobispo de Toledo quien procediera a su consagración, entre el 4 de febrero de 1239 y el 20 de junio del mismo año. En la primera fecha el rey Fernando III hace una donación a la Iglesia de Córdoba y a su obispo electo y en la segunda el mismo rey designa, entre otros jueces, al ya obispo de Córdoba, maestro Lope, para determinar ciertos límites entre los concejos de Segovia y Madrid ${ }^{8}$. También cabe pensar, que en el año de la elección del nuevo obispo los representantes del arzobispo

${ }_{4}$ Burgos, 9 de Mayo de 1237. J. GonZÁLEZ, Reinado y diplomas de Fernando III. T.III. Córdoba, 1986, pp. 129-130. C. EuBEL, Hierarchia Catholica Medii Aevi. T.I. Monasterii, 1913, p. 208. En adelante no pondremos en nota las citas a este último autor, a no ser estrictamente necesario, pues son fáciles de comprobar.

5 Biblioteca del Cabildo Catedralicio de Córdoba (=B.C.C.), Ms. 125, f. 126. Martín Ruiz el del obispo vivía en la collación de San Nicolás de la Villa de Córdoba. Ibidem, f. 94. Gonzalo Pérez de Fitero era vecino de la collación de Santa María de Córdoba.

${ }^{6}$ Rieti, 26 de junio de 1234. A. POTTHAST, Regesta Pontificum Romanorum. Inde ab anno post Christum natum MCXCVIII ad annum MCCCIV. Berlín, 1875, n. 9.481.

7 M. Nieto Cumplido, Corpus Mediaevale Cordubense.I (1106-1255). Córdoba, 1979, pp. 151-152.

8 Valladolid, 12 de diciembre de 1238. B.C.C., Ms. 125, ff. 4-5. Biblioteca Nacional de Madrid (=B.N.), Ms. 13.077, ff. 23-26. R.A.H., Ms. 9/5.430, ff. 1-10 y Ms. 9/5.436, ff. 518-519. J. GoNZÁLEZ, Reinado y diplomas de Fernando III. 3 vols. Córdoba, 1980-1986. III, pp. 183-186. 
de Toledo en la curia romana no sólo consiguieran bula de confirmación de la designación del nuevo obispo de Córdoba, por cuya noticia daría Eubel la fecha ya dicha de 9 de mayo de 1237, sino también otras dos bulas, ahora a favor de Fernando III. En ellas se concedía al rey poder presentar ante el obispo de Córdoba a cuatro prebendados de la catedral (Viterbo, 28 de agosto de 1237) y poder presentar por vez primera a los rectores de las iglesias (Viterbo, 12 de septiembre de 1237).

En cuanto a su extracción social, a falta de noticias directas, puede pensarse en su adscripción a una familia de hidalgos de Fitero en Burgos, cuyos miembros debieron servir al rey como vasallos y en la conquista de Córdoba, por lo que acabaría asentándose en esta ciudad. En definitiva, ser capellán real comportaba unos lazos personales parangonables a los de los vasallos y hombres del rey.

Con sus colaboradores más cercanos, su sobrino Martín de Fitero, su capellán don Fernando y ciertos prebendados de la catedral e iglesias de la ciudad, procedería nuestro obispo a la organización de las iglesias y su culto. También a la distribución de los clérigos y erección de parroquias y beneficios dotados, manteniendo la catedral como centro fundamental de la vida eclesiástica, mientras gradualmente ésta se imponía en la ciudad y diócesis. Parece que mantuvo no sólo mesa común con los capitulares de la catedral, sino también con gran parte del clero de la ciudad.

Debió morir el 10 de junio de 1245, según la fecha que dan Eubel y Gómez Bravo y que cabe colegir del libro de memorias de aniversarios y fiestas correspondiente o Libro Verde. Según Nieto Cumplido, fue sepultado ante las gradas del altar mayor de la catedral ${ }^{9}$.

\section{Don GutierRe Ruiz De Olea (23 de marzo de 1246 a abril de 1249).}

El sucesor del obispo difunto don Lope de Fitero parece repetir en muchos aspectos a su antecesor. Según todos los indicios, fue provisto por el papa Inocencio IV a petición del rey Fernando III. No consta su elección por parte del cabildo catedralicio o parte del mismo, aunque era canónigo de Córdoba y prebendado en la catedral de Burgos, seguramente como dignidad ${ }^{10}$. Posiblemente su designación tampoco contó con el asentimiento general del clero de la ciudad de Córdoba.

\footnotetext{
9 B.C.C., Libro Verde. ff. 72 y 98. M. NIETo CUMPLIDO, Historia de la Iglesia, p. 128.

10 La bula de presentación, de Lyon, 23 de marzo de 1246, dice que era canónigo de Córdoba, como veremos en la nota siguiente. También gozaba de «portiones praestimoniales» en Burgos. E. BERGER, Les Registres d'Innocent IV, n. 1763.

Episcopado Hispano

Hispania Sacra 54 (2002)
} 
En la bula de presentación del nuevo obispo, dirigida al «clero civitatis et diocesis Cordubensis» se alude a su elección con un genérico «eligeretur» y a la alegría producida en la casa y corte de Fernando III. Pero se da a entender, que gran parte del clero se opuso y seguía oponiéndose a tal elección y posiblemente hubiera intentado impedirla de algún modo. En efecto, no consta la elección capitular de este obispo y Mansilla Reoyo coloca precisametne en este caso la inauguración del sistema de presentación ante el papa ${ }^{11}$.

Por el tiempo de su provisión a la sede se desarrollaron en la ciudad de Córdoba varios alborotos y discordias entre los miembros más conspicuos de la misma, caballeros y clérigos. Esto parece poder colegirse de las bulas conseguidas por el obispo don Gutierre en la curia pontificia: sobre los clérigos concubinarios y excomulgados (Lyón, 18 de marzo de 1246), sobre perdón a cuarenta legos que cometieron violencia contra los clérigos (Lyón, 22 de marzo de 1246) y la misma bula de recomendación aludida.

Seguramente estos tumultos hay que ponerlos en relación con varios motivos, la mayoría de los cuales están patentes en la sentencia del cardenal Gil Torres de 1250, mientras que la solución propuesta por el rey Fernando III parece ser la jerarquización socioeconómica en la ciudad y la salida de las conquistas de Jaén y Sevilla, uno de cuyos principales brazos ejecutores sería la familia de los Ruiz de Olea y el propio obispo don Gutierre.

Esta interpretación es verosímil, ya que esta familia burgalesa ${ }^{12}$ aportó a un hermano del obispo como adelantado mayor de la frontera (1253), don Pedro

${ }^{11}$ Lyón, 23 de marzo de 1246. E. BERGER, Les Registres d'Innocent IV, n. 1.757. Por la importancia de esta bula, entresacamos lo más importante de su texto: «Clero civitatis et diocesis Cordubensi vacante venerabilis frater nostre G. episcopus, tunc ecclesie canonicus Cordubensis, in pastorem ipsius eligeretur ecclesie, carissimo in Christo filio nostro... illustri regni Castelle et Legionis, ac... regine uxori et A. primogenito suis et regni sui baronibus et etiam populo Cordubensi exultatio inmensa provenit pro eo quod, cum idem sit genere potens et nobilis..., a vobis et ab aliis supradictis de ipso firma fiducia ducebatur quod eidem ecclesie per industrie sue subsidium processu temporis multitudo proveniret commodi et honoris. Nos quidem ... providere volentes ne per diutine vacationis dispendium aliquod ipsa paretur ecclesia detrimentum, sibi dictum G. prefecimus in pastorem et eidem, nolentes tamen in posterum per hoc alicui preiudicium generari, munus consecrationis manibus nostris impendimus ... Quocirca universitatem vestram rogandam duximus et monendam precipiendo mandantes quatinus eumdem, cum ad vos pervenerit, admitentes hilariter et devote, ac sibi tanquam pastori vestro debitam obedientiam et reverentiam impendentes, eius salubribus mandatis et monitis efficaciter intendatis ... Alioquim sententiam quam idem rite tulerit in rebelles ...) D. MANSILla REOYO, Iglesia Castellanoleonesa y Curia Romana en los tiempos del rey San Fernando. Madrid, 1945, p. 182.

12 Véase J. GoNZÁLEZ, Reinado.I, p. 438. Además, don Gutierre no era sólo canónigo de Córdoba, sino también prebendado en la catedral de Burgos, obteniendo del papa Inocencio IV poder disfrutar por cuatro años de las rentas de esta prebenda a causa de la pobreza de la Iglesia de Córdoba, por bula de Lyón, 21 de marzo de 1246. E. BERGER, Les Registres, n. 1.763. D. MANSILLA REOYO, Iglesia, p. 333. 
Ruiz de Olea, y a otro hermano, don Gonzalo, como destacados conquistadores, de Jaén y Sevilla, a cuya expugnación acudió el obispo don Gutierre con las armas y con la consagración de las mezquitas mayores de ambas ciudades ${ }^{13}$. Además, el mismo obispo consiguió dos bulas de Cruzada a su favor ${ }^{14}$. Que el rey Fernando III tenía grandes proyectos para su candidato don Gutierre se demuestra por su promoción al arzobispado de Toledo en 1249.

Así, pues, puede entenderse la expresión pontificia de que lo eleva al episcopado para evitar los daños de una larga vacación de la sede cordobesa, contenida en la bula de presentación. Si bien su desiganción pontificia debió ser anterior a la fecha de ésta (23 de marzo de 1246), que es la que ofrece Eubel. Así aparece como confirmante «Gutierrius Roderici, electus Cordubensis» en 31 de diciembre de 1245. Pero la misma cancillería regia vacila, de manera que en fechas posteriores aparece la Iglesia de Córdoba como vacante. Nieto Cumplido opina, que tal vacilación se debería a la controversia sobre el designado y que sólo se aclararía a partir de su presencia en Lyon en el mes de marzo de $1246^{15}$.

Junto al problema de la designación por el pontífice, aparece el de la consagración como obispo por el mismo Inocencio IV, en lo cual advierte el papa que no pretende por este acto causar ningún perjuicio a ninguna sede metropolitana, antes del 18 de marzo de 1246. Tal consagración puede interpretarse como el deseo del rey, del electo y del pontífice por resolver cuanto antes la grave situación, que venía padeciendo la ciudad e Iglesia de Córdoba desde el verano anterior. En efecto, aún no podía existir pleito alguno por la adscripción de la sede cordobesa a ninguna metrópoli, que no fuera la de Toledo, lo que se vuelve a recalcar en $1247^{16}$.

En cuanto a la extracción social del obispo don Gutierre Ruiz de Olea, hay que hablar de su pertenencia a una familia, como dice la bula de presentación,

${ }^{13}$ Sevilla, 21 de febrero de 1253. Pedro Ruíz de Olea figura entre los confirmantes de este privilegio rodado concedido por Alfonso X a la catedral de Toledo. Memorial Histórico Español. Madrid, 1851, T.I, pp. 5 y 8-10. J. GOMEZ BRAVO, Catálogo.I, p. 259. Además Pedro Ruiz de Olea recibió de Fernando III donadíos en Córdoba y junto con su hermano el obispo don Gutierre una heredad en Cuevas de Carchena de manos del concejo de Córdoba en 18 de septiembre de 1246. B.C.C., Ms. 125, f. 50.

${ }^{14}$ Lyon, 22 de marzo de 1246. E. BERGER, Les Registres d'Innocent IV, nn. 1.758 y 1.760.

15 Sitio de Jaén, 31 de diciembre de 1245. I. ORTEGA Y COTES, Bullarium Ordinis Militiae de Calatrava, pp. 83-85. M. DE MANUEL RODRÍGUEZ, Memorias para la vida del Santo rey don Fernando III. Madrid, 1800, pp. 479-481. J. GONZÁLEZ, Reinado.III, pp. 290-293. M. NIETO CUMPLIDO, Historia de la Iglesia, p. 129. A. QUINTANA PRIETO, La documentación pontificia de Inocencio IV (1243-1254), Roma, 1987, 2 vols. I, nn. 258-265, pp. 286-290.

16 Lyón, 12 de abril de 1247. Inocencio IV, en bula dirigida al arzobispo de Toledo, hace constar que con esta consagración el papa no pretendió «tibi vel ecclesie Toletanae aliquod preiudicium generetur». E. BERGER, Les Registres, n. 2.604.

Episcopado Hispano

Hispania Sacra 54 (2002) 
de «genere potens et nobilis», la de los Ruiz de Olea de Burgos asentados en Córdoba. Unido a esto va su constante cooperación militar y eclesiástica junto al rey Fernando III. Nuestro obispo aparece como buen guerrero ensalzado por las crónicas ${ }^{17}$, identificado con los ideales fernandinos de la unión de monarquía, milicia e iglesia en la tarea conquistadora. No consta su cualificación intelectual, pero hemos de suponer que contara con algún grado universitario, puesto que había tenido tiempo y beneficio suficiente en la Iglesia de Burgos.

Como obispo de la ciudad destaca su labor de poner orden en la misma y en su Iglesia, quizá sancionando la jerarquización socioeconómica y profesional, que comenzaba a asentarse en la ciudad diez años después de su conquista. Esto tendrá especial reflejo en la creación y organización interna del cabildo catedralicio y su diferenciación con el resto del clero de la ciudad (división de las mesas episcopal y capitular, creación de dignidades, canonjías y raciones, etc.).

También destaca el acrecentamiento de las posesiones de la Iglesia de Córdoba, con varias donaciones regias y concejiles y la ordenación de las rentas eclesiásticas por su constitución de 1 de abril de 1249, cuando ya debía conocer la postura favorable del cardenal Gil Torres a sus determinaciones en las querellas surgidas con anterioridad.

Igualmente debe caber en su obra la consolidación parroquial de la ciudad y de muchas otras villas importantes del obispado.

Aunque la notificación de su promoción al arzobispado de Toledo es de 6 de febrero de 1249, su actuación en Córdoba continuaba en el mes de abril de este año. Pero ya aparece como arzobispo de Toledo en la confirmación del privilegio de 30 de mayo de $1249^{18}$.

\section{Don PEDRo IBÁÑEZ (febrero de 1250 a 26 de abril de 1251).}

La existencia de este obispo es ignorada por Gómez Bravo, mientras que Ramírez de Arellano hace conjeturas a partir de las listas de confirmantes de privilegios reales ${ }^{19}$. La curia regia no debía estar informada directamente desde la curia pontificia, sino por los propios eclesiásticos, por lo que en este espacio de tiempo en las listas de confirmantes tanto aparece «ecclesia Cordubensis vacat» como «Petrus Cordubensis episcopus». La primera vez que aparece este obispo en las listas es en 20 de abril de 1250, sin embargo Mansilla Reoyo

17 Primera Crónica General, pp. 746-747 y 757-758.

18 Lyon, 6 de febrero de 1249. E. BERGER, Les Registres, n. 4.341. A. POTTHAST, Regesta, n. 13.204. A. QUINTANA PRIETO, La documentación pontificia de Inocencio IV, II, nn. 572 y 573, pp. 528-529. Sevilla, 30 de Mayo de 1249. J. GonZÁLEZ, Reinado.III, pp. 352-353.

19 R. RAMIREZ DE ARELlano, Historia de Córdoba.IV, p. 17. 
dice que ya en febrero de 1250 era obispo de Córdoba don Pedro Ibáñez, capellán pontificio y residente en la curia papal ${ }^{20}$.

Así, parece que el episcopado breve de don Pedro Ibáñez fue una imposición (legítima por constituir vacante in curia la promoción de don Gutierre) del papa Inocencio IV, frente a las propuestas del rey Fernando III y a la elección nula del cabildo catedralicio de Córdoba en la persona de don Lope Pérez.

Don Pedro Ibáñez era arcediano de León, camarlengo del cardenal Gil Torres, capellán pontificio y curial residente junto al pontífice. El mismo papa escribirá a los cordobeses, que su nuevo obispo se hallaba momentáneamente impedido de personarse en su diócesis. No obstante, cabe pensar que en su breve pontificado no debió apartarse de sus trabajos en la curia pontificia. Desde la misma gobernaría su diócesis, ayudado por los informes y consejos del arcediano de Córdoba don Miguel Díaz.

Su influencia en la curia hizo emanar de la misma una serie de bulas dirigidas al obispo de Córdoba, tocantes a la salvaguardia de los derechos del clero parroquial frente a los religiosos de la ciudad cordobesa (Lyon, 5 de abril de 1250). Al trato con los judíos (su obligación de pagar ciertos diezmos y de portar signos distintivos en el vestido, de Lyon, 11 de marzo de 1250, y la prohibición de construir una sinagoga de orgullosa altura, Lyon, 12 de abril de 1250). A la resolución del conflicto que aún permanecía latente y que enfrentaba ante la curia papal al menos desde 1248 al obispo y cabildo catedralicio, de una parte, y al clero y al concejo de la ciudad, de otra, mediante la sentencia del cardenal Gil Torres de 1250. A la consecución de indulgencias en favor de las limosnas de la catedral (Lyon, 11 de mayo de 1250) y a la delimitación de los términos del obispado de Córdoba (Lyon, 21 de mayo de 1250). Todo lo cual no impidió que su sucesor recibiera una herencia deteriorada. Su traslado a la sede de Oviedo se produciría antes del 26 de abril de 1251.

4. EL ELECTO DON LOPE PÉREZ DE RETES (13 de febrero de 1252 a 9 de octubre de 1257).

Con la promoción de don Pedro Ibáñez al obispado de Oviedo nuevamente se producía vacante in curia. Sin embargo, en esta ocasión el papa Inocencio IV accedió a confirmar como obispo de Córdoba al elegido por el cabildo catedralicio en 1249, don Lope Pérez. De él tenemos la primera noticia como electo en Perusa, 13 de febrero de $1252^{21}$, donde el papa concede a su capellán, Bernardo,

20 D. MANSIlla ReOyo, Iglesia, pp. 180-181.
21 E. BERger, Les Registres, n. 6.758. 
que no se le cause perjuicio alguno por la colación de una prebenda canonical en Palencia, que anteriormente había disfrutado don Lope electo de Córdoba.

En cuanto a su extracción social, dice Gómez Bravo que era hermano del conquistador de Córdoba y asentado en la ciudad don Juan Pérez de Retes ${ }^{22}$, llamado también Juan Pérez del electo. Fue hijo ilegítimo del noble Lope Díaz, obteniendo la dispensa ex defectu natalium para acceder a todas las órdenes sagradas, siendo ya maestro ${ }^{23}$. Había sido canónigo de Palencia, además de canónigo de Córdoba y criado de los reyes Fernando III y doña Beatriz, continuando al servicio del rey Alfonso $\mathrm{X}^{24}$. Consecuentemente, nos encontramos ante un caso similar al de los dos primeros obispos, especialmente el de don Lope de Fitero.

Renunció al episcopado, siendo electo sin consagrar, quizá debido al debate suscitado entre la metropolitana de Toledo y la reciente sede arzobispal de Sevilla por la adscripción de la sede cordobesa, lo que conllevaba el derecho de consagración de los obispos sufragáneos.

Nuestro electo, durante su estancia en la curia pontificia para obtener la confirmación de su elección, tuvo la precaución de proveerse de varias bulas con las que ponerse a salvo de las consecuencias de esta disputa. Que nadie pudiera excomulgarle, suspenderle o poner entredicho sobre su Iglesia (Perusa, 5 de marzo de 1252). Que nadie pudiera obligarle a él ni a su cabildo catedralicio a conceder beneficios eclesiásticos en su Iglesia (Perusa, 5 de marzo de 1252). Sobre todo, poder ser consagrado por el obispo de Jaén ${ }^{25}$, a pesar de lo cual no conseguirá fruto alguno en este asunto y su consagración nunca se realizará.

También su estancia en la curia pontificia en 1252, acompañado del arcediano de Córdoba, don Miguel Díaz, produjo la obtención de otras bulas, especialmente de concesión de indulgencias para las limosnas que se hicieran a la catedral. Pero también la consecución de otras dos no menos importantes. Una sobre la reconstitución del patrimonio, bienes y rentas de la mesa episcopal (Perusa, 5 de marzo de 1252). Otra sobre la ejecución de la sentencia del cardenal Gil Torres de 1250 (Perusa, 7 de mayo de 1252).

22 El testamento de don Juan Pérez de Retes es de Córdoba, 21 de febrero de 1286, siendo vecino de la collación de Santa María de Córdoba y fundador de la capilla de San Benito de la catedral. B.C.C., Ms. 125, ff. 55-57.

23 I. RODRÍGUEZ DE LAMA, La documentación pontificia de Alejandro IV (1254-1261).Roma, 1976, n. 398.

24 Toledo, 28 de marzo de 1254. Archivo de la Catedral de Córdoba (=A.C.C.), caj. P, nn. 76,77,78 y 85. B.C.C., Ms. 125, ff. 7-8. B.N., Ms. 13.077, ff. 35-38. Juan Pérez del electo era vecino de la collación de Santa María de Córdoba en 4 de diciembre de 1274. B.C.C., Ms. 125, f. 96.

25 Perusa, 19 de febrero de 1253. El papa Inocencio IV manda al obispo de Jaén que consagre obispo al electo de Córdoba, dado que era incierta la adscripción de esta diócesis a la metrópoli de Toledo o a la de Sevilla, sin que por ello se prejuzgue nada sobre el resultado del litigio. E. BERGER, Les Registres, n. 6.377. 
No se sabe si volvió a Córdoba en 1252, pero nuevamente se encontraba en la curia pontificia en 1253, aunque esta vez será más duramente tratado, a causa de las deudas con los prestamistas italianos, como Bonifacio Bonsignore de Siena (Perusa, 13 de febrero de 1253) y Timoso Aconti de Florencia (Perusa, 11 de marzo de 1253).

De vuelta a su diócesis en el verano de 1253 debió acometer la ingrata tarea de reconstruir un obispado en ebullición, con intereses encontrados y con unos recursos episcopales dilapidados y aún perdidos en gran medida, a causa de la ausencia de su antecesor y las complicaciones de su confirmación y consagración.

De todos modos, conseguirá para su Iglesia el diezmo de los almojarifazgos de Hornachuelos, Morata, Estepa, Aguilar, Benamejí, Santaella, Cabra, Biervén, Zuheros, Zuherete, Luque y Baena en $1254^{26}$. También la reorganización en la percepción de los diezmos eclesiásticos y la defensa de la inmunidad del señorío eclesiástico, con ayuda del rey Alfonso X.

Pero debió llegar abrumado por las dificultades. Más aún cuando en 1257 todavía le perseguían por sus deudas contraídas en la curia pontificia al final de su episcopado ${ }^{27}$. Según Eubel, renunció o resignó el episcopado en este año, como también lo afirma Gómez Bravo.

Debió morir este mismo año de 1257, en 9 de octubre, según se desprende del Libro Verde ${ }^{28}$, en el aniversario encargado por el testamento de don Juan Pérez de Retes.De su actividad legisladora quedan algunos estatutos otorgados al cabildo catedralicio.

5. DON FERNANDO DE MESA ( 7 de diciembre de 1257 a 16 de noviembre de 1274).

El cabildo catedralicio de Córdoba, reunido en la catedral y presidido por su deán don Gonzalo el día 7 de diciembre de 1257, eligió como obispo a don Fernando de Mesa, abad de Santillana, y al día siguiente formó una comisión, que pidiera en su nombre la oportuna confirmación al arzobispo de Toledo. Aceptada

26 Toledo, 11 de marzo de 1254. B.C.C., Ms. 125, f. 82. A. ARJONA CASTRO, Zuheros, pp. 197198. Toledo, 28 de marzo de 1254 . A.C.C., caj. P, ns. $76,77,78$ y 85. B.C.C., Ms. 125 , ff. 7-8. B.N., Ms. 13.077, ff. 35-38. Burgos, 2 de noviembre de 1255. B.C.C., Ms. 125, f. 82. B.N., Ms. 13.077, ff. 46-48. R.A.H., Ms. 9/5.436, ff. 536-538. Burgos, 3 de noviembre de 1255. A.C.C., caj. P, ns. 23,24,26 y 31 . B.C.C., Ms. 125 , f. 83 .

${ }^{27}$ Letrán, 28 de enero de 1257. B.C.C., Ms. 125, f. 4.

28 B.C.C., Libro Verde, f. 47. 
la elección y antes de su consagración episcopal, seguramente a finales del año 1257, nuestro electo prometió obediencia al metropolitano de Toledo ${ }^{29}$.

Era capellán del rey Alfonso X. Aunque desconocemos su especialización cultural, ha de pensarse en un título de maestro, dados los cargos que ostentó antes de ser elegido obispo. Estuvo presente en la conquista de Sevilla, recibiendo en 1253 un donadío de cincuenta aranzadas de olivar e higueral en la aldea sevillana de Pilas ${ }^{30}$. Gracias a esta amistad con el rey, Alfonso X resarce a la Iglesia de Córdoba con 1.000 mrs. chicos en el almojarifazgo de Ecija por el paso de esta ciudad a la Iglesia de Sevilla en 1258 y concede a la Iglesia cordobesa las tercias reales en $1260^{31}$. Sin embargo, la donación más importante provendrá del concejo de Córdoba, confirmada por Alfonso X, del castellar de Río Anzur en $1258^{32}$ y además consigue del rey, en atención a su persona y por el tiempo de la vida del obispo, que Bella sea considerada «casa llana» ${ }^{33}$, amén de otras ayudas, especialmente en asuntos de diezmos e inmunidad eclesiástica.

Según Gómez Bravo, procedía nuestro obispo de los caballeros Mesa de Toledo. Según García Caraffa y el autor de la Casa de Cabrera en Córdoba, procedía de Trujillo, siendo hijo tercero de Fernando González de Mesa y de Mencía Chaves, señora de varios lugares, y hermano de Gonzalo, Alfonso y Ruy $^{34}$. Los dos últimos intervinieron en la conquista de Córdoba y su familia quedó vinculada a la monarquía y asentada en la ciudad. Además, Alfonso casó con Catalina de Sousa, hija del conquistador portugués Gil Gómez de Sousa, y fue comendador mayor de Córdoba, y su hijo Ruy fue deán de Córdoba.

El episcopado de don Fernando de Mesa resultó ser el de mayor eficacia administrativa, después de casi diez años de práctico desgobierno y dificultades. En cuanto a la red parroquial, ya se vieron sus campañas de 1260 y 1272 en nuestro libro sobre la geografía del Obispado de Córdoba ${ }^{35}$. Pero hay que señalar que debió efectuar algunas más, como la que parece entreverse en 1266 en Castro del Río, lo que se completó con varias concordias con señores de castillos y villas. Así las de 1260 con don Gonzalo Ibáñez Dovinal por Aguilar, las de 1260 y 1272 con la Orden de Santiago por Estepa y Benamejí, o la

\footnotetext{
${ }^{29}$ Córdoba, 8 de diciembre de 1257. B.N., Ms. 13.035, ff. 138-139 y 132.

30 Sevilla, 13 de junio de 1253. A. BALleSTEROS, Sevilla en el siglo XIII. Madrid, 1913, doc. 19.

31 Valladolid, 21 de febrero de 1258. B.C.C., Ms. 125, ff. 9 y 83-84. B.N., Ms. 13.077, ff. 49-52. R.A.H., Ms. 9/5.436, f. 541. Córdoba, 6 de julio de 1260. A.C.C., caj. P, n. 238. B.C.C., Ms. 125, f. 12. B.N. Ms. 13.077, f. 53. R.A.H., Ms. 9/5.430, ff. $43-44$ y Ms. 9/5.436, f. 544.

32 Córdoba, 22 de septiembre de 1258. B.C.C., Ms. 125, f. 13. R.A.H., Ms. 9/5.436, ff. 178-180. Confirmación real en Madrid, 11 de diciembre de 1258. A.C.C., caj. N, ns. 25 y 36. B.C.C., Ms. 125, f. 13. 33 Córdoba, 24 de noviembre de 1268. B.C.C., Ms. 125, f. 19.

34 A. y A. GARCÍA CARAFFA, Enciclopedia heráldica y genealógica hispanoamericana. Madrid, 1919-1961. Vol. 62, pp. 231-232. La Casa de Cabrera en Córdoba. Córdoba, 1779, p. 431.

35 I. SANZ SANCHO, Geografia del Obispado de Córdoba en la Baja Edad Media. Madrid, 1995. 
de 1267 con el infante don Rodrigo Alfonso por Baena y Cabra. Seguramente hay que poner en su haber la firma de la constitución sobre el ganado extremeño con el arzobispado de Sevilla y los obispados de Cádiz y Silves.

También emprendió la recuperación y reorganización de los bienes de la mesa episcopal, especialmente a través de varias permutas con el cabildo catedralicio, como la de 1260 y 1264 . Esto le permitió un redondeamiento de sus posesiones, e incrementar el carácter señorial de las mismas, a la vez periféricas y más concentradas, lo que proporcionaría mejoras en la gestión.

Igualmente abordó la reorganización económica del cabildo catedralicio, estableciendo más claramente las rentas del comunal del mismo, las de pitanzas y los préstamos capitulares, para lo cual había sido esencial la creación de la red parroquial.

En efecto, en la estimación de préstamos canonicales de 1264 ya se produjo un vuelco esencial al situar estos préstamos mayoritariamente en las parroquias, manteniendo la excepción de que algunos capitulares siguieran disfrutándolos en aquellos lugares que pertenecían al comunal. El cambio definitivo y total fue en 1272, cuando los préstamos canonicales se situarán en el derecho a la parte del cabildo catedralicio en determinadas parroquias.

El correlato debió ser establecer por esas fechas las parroquias en las que se situarían los préstamos de racioneros y compañeros del cabildo.

A la vez hubo de afrontar la definitiva reorganización del cabildo catedralicio en 1265, creando veinte medias raciones, procedentes de la división por mitad de diez raciones. Además, otorgó varios estatutos al cabildo sobre facultad de testar de los capitulares, orden a seguir en la promoción a dignidades, residencia mínima para ganar el vestuario los canónigos, etc.

En su relación con el cabildo catedralicio, parece que quiso ejercer cierto control sobre el mismo y también sobre el resto de las iglesias del obispado. De este modo se aseguró la facultad de distribuir las prestameras de las iglesias rurales en $1268^{36}$ y cierta discrecionalidad en cuanto a la concesión de liberalidades a los capitulares en $1269^{37}$.

Esto no dejó de crear suspicacias entre los prebendados, que delegaron en los canónigos Aznar Pérez y Juan Pérez para que acudieran al arzobispo de Toledo, solicitando del mismo que interpusiera su autoridad sobre los actos jurídicos principales, que establecieron las posesiones y rentas de la mesa capitular de los años $1249,1260,1264$ y $1269^{38}$.

\footnotetext{
${ }^{36}$ Córdoba, 25 de marzo de 1268. B.C.C., Ms. 125, f. 40 y Ms. 166, f. 20.

37 Córdoba, 10 de noviembre de 1269. A.C.C., caj. N, n. 49. B.C.C., Ms. 125, f. 38 y Ms. 166, f. 7.

38 Copia sin fecha de los documentos de 1 de abril de 1249, 19 de junio de 1260, 8 de enero de 1264 y 10 de noviembre de 1269. A.C.C., caj. N, n. 49.
} 
Continuó con la política de préstamos de bienes de la Iglesia en favor de varios personajes de la ciudad, iniciada por don Lope de Fitero. Si bien dio un recorte radical, al limitar ese tipo de préstamos a sólo los capitulares. Pero sobre todo impulsó, si es que no inició, una activa puesta en explotación de las posesiones donadas a la Iglesia por el rey Fernando III en la Sierra de Córdoba (la tercera parte del olivar reservado al rey) en el pago de Cózar, entregando pequeños lotes en régimen de enfiteusis, de lo que queda constancia en varios contratos de 1270.

Debió morir el 16 de noviembre de 1274, según los oficios y capilla de Santiago de la catedral que dotó y que constan en el Libro Verde, siendo enterrado en la capilla de Santiago de la catedral, que había fundado ${ }^{39}$. Sus restos se conservan en la actual sepultura llamada de los Cinco Obispos.

\section{DON PASCUAL (1274 a 9 de febrero de 1293).}

Las fechas del comienzo y del final del episcopado de don Pascual, al igual que su adscripción familiar, son imprecisas. Parece que fue elegido por el cabildo catedralicio, aunque no haya documentación por la que conste, a finales de noviembre o principios de diciembre de 1274 y quizás no tan «unanimiter» como su antecesor, a juzgar por el temprano enfrentamiento que tuvo con su cabildo.

Según Ramírez de Arellano, ya era obispo electo en 1 de diciembre de $1274^{40}$, pero Eubel y Gómez Bravo son más imprecisos, señalando únicamente el año de 1274. Igualmente, estos últimos autores son imprecisos en cuanto al año de su muerte, indicando que fue en 1292 ó 1293, aunque la fecha de 9 de febrero, que ofrece Gómez Bravo, está tomada del Libro Verde ${ }^{41}$.

La fecha de la siguiente elección episcopal no saca de dudas, toda vez que en 1295 Fernando IV dio su cuaderno de prelados, en el que se reconocían ciertos abusos de la Corona en cuanto a las elecciones episcopales y a la gestión de bienes de los obispos difuntos. Es decir que pudo darse una larga vacancia en la provisión de la sede de Córdoba, aún cuando parezca razonable situar la muerte de don Pascual en 1293.

Nuestro obispo anteriormente fue canónigo extravagante en Córdoba, permutando esta prebenda por otra canonjía mansionaria en 1264 con licencia pontificia. Sucedió en la maestrescolía a don Martín de Fitero en 1272, al ascender éste al arcedianato de Córdoba. Era por tanto maestrescuela cuando fue

\footnotetext{
${ }^{39}$ B.C.C., Libro Verde, ff. 65-68.

40 R. RAMÍREZ DE ARELlANO, Historia de Córdoba. IV, pp. 51-52.

41 B.C.C., Libro Verde, ff. 105-107.
} 
elegido obispo por sus compañeros del cabildo catedralicio ${ }^{42}$. Es decir, tendría el grado de maestro.

Ignoramos su extracción social, aunque cabe situarlo entre las familias de hidalgos establecidos en Córdoba. El Libro Verde únicamente dice que dejó fundadas memorias por sus padres y por Domingo Martín y su mujer doña María. En cualquier caso dejó un buen número de posesiones como dotación de oficio. Según Gómez Bravo, fundó el Hospital de Ahogados, situado entre el Guadalquivir y la catedral, en el que mandó enterrarse, pero que desapareció posteriormetne a causa de las crecidas del río y su cuerpo fue trasladado a la catedral por el obispo don Iñigo Manrique. Según Nieto Cumplido, no hay constancia documental de la fundación de tal hospital, ni del traslado de sus restos. A finales del siglo XV su sepultura estaba a los pies de la capilla de Villaviciosa, en la catedral, bajo los órganos. Desde el siglo XVI su sepulcro se halla bajo el órgano del lado del Evangelio ${ }^{43}$.

La primera noticia documentada del episcopado de don Pascual contiene la compra, que éste hizo de un solar junto al fonsario de Santa María en 20 de agosto de 1276, que, ya edificado, constituyó parte de su donación pro ani$m a^{44}$. No obstante, el solar era para la fábrica de la catedral, de cuya dotación se preocupó, al institucionalizar la renta de los excusados de la misma en las parroquias de la ciudad en 1277.

A poco de ser elegido obispo tuvo un grave enfrentamiento con el cabildo catedralicio, al parecer por continuar la política episcopal de sus antecesores de sanear y aumentar las rentas de la mesa episcopal, según el cabildo a costa y en perjuicio de la mesa capitular. Por ello éste acude ante el tribunal pontificio. En 1277 el papa Nicolás III mandó al obispo y al chantre de Jaén, que determinasen en la causa, presentada ante el papa por el cabildo catedralicio de Córdoba contra su obispo, alegando que recibía injurias sobre los derechos a los diezmos, tierras, posesiones, derechos capitulares y otros asuntos, seguramente relacionados con el tema de la provisión de canonjías ${ }^{45}$.

\footnotetext{
42 M.J. GIRAUD, Les Registres d'Urbain IV, n. 2.113. I. RODRÍGUEZ DE LAMA, La documentación pontificia de Alejandro IV (1254-1261). Roma, 1976, n. 326. El maestrescuela don Martín de Fitero acababa de acceder al arcedianato de Córdoba en 29 de marzo de 1272. A.C.C., caj. N, n. 86. B.C.C., Ms. 125, ff. 67-68 y Ms. 166, 13-14. B. FRESNEDA, Estatutos de la Sancta Yglesia, pp. 61-62. Don Pascual aparece documentado como maestrescuela en Córdoba, 10 de agosto de 1272. A.C.C., caj. R, n. 1.

43 M. Nieto CUMPLIDO, Historia de la Iglesia, p. 166.

${ }^{44}$ Córdoba, 20 de agosto de 1276. B.C.C., Ms. 125, f. 95. Libro Verde, ff. 105-107.

45 Roma, 30 de marzo de 1277. B.C.C., Ms. 125, f. 4.1 de agosto de 1288. Ibidem, f. 38 . Ms. 166, f. 14. R.A.H., Ms. 9/5.430, f. 45. Por su parte, S. DomíngUEZ SÁNCHEZ, Documentos de Nicolás III (1277-1280) referentes a España, Universidad de León, 1999, n. 12, p. 188, lo fecha en Roma, 30 de marzo de 1278.
}

Episcopado Hispano

Hispania Sacra 54 (2002) 
De su legislación reseñamos varios estatutos capitulares. El de 1285 sobre la obligación de que los prebendados diezmaran de todos sus bienes, para que después se distribuyera en los repartos cotidianos a los asistentes a los oficios. El de 1288 sobre la facultad de testar. El de 1290, estableciendo las condiciones de ascenso en las categorías del cabildo.

Pero sobre todo hay que subrayar su legislación sobre cuestiones decimales. Se trata de las dieciséis «leyes» otorgadas en 1277, seguramente en el mes de mayo, cuya vigencia se extendió por toda la Edad Media, ya que se recogen en las Constituciones del Obispado de Córdoba del obispo don Iñigo Manrique ${ }^{46}$.

Otros puntos importantes de su episcopado fueron los problemas de la inmunidad del señorío eclesiástico. La eventual posibilidad de recuperar Ecija para el obispado cordobés. La querella entre las metropolitanas de Sevilla y Toledo por la adscripción a su provincia de la diócesis de Córdoba. La delimitación de la parroquia de Adamuz en 1288.

El obispo don Pascual, en defensa de la jurisdicción eclesiástica, consiguió del rey Sancho IV en 1282, en primer lugar, que la Iglesia de Córdoba dispusiera de un portero, franco de todo pecho con excepción de la moneda forera, con facultad de prender a los mudéjares y judíos que no entregasen a la Iglesia los derechos debidos. En segundo lugar, que el concejo de Códoba no obligase a la Iglesia a pechar juntamente con éste en las añudas, porque debían pechar diferenciadamente, según el fuero de Córdoba dado por Fernando III ${ }^{47}$.

Entre sus colaboradores aparecen su capellán Bernart, compañero en el cabildo catedralicio, y su vicario don Aznar Pérez, arcediano de Castro y canónigo de Córdoba.

7. Don Gil DomingueZ (11 de mayo de 1294 a noviembre de 1299).

A la muerte del obispo don Pascual, se produjo, en un momento indeterminado, la elección «unanimiter» para obispo de Córdoba del maestrescuela de León, don Juan Fernández. La relación que presentó el cabildo catedralicio ante el arzobispo de Toledo, don Gonzalo García Gudiel, en 1294, pidiendo la confirmación del nuevo electo por el mismo cabildo, don Gil Domínguez, parece

46 B.C.C., Ms. 125, ff. 90-91. Constituciones del Obispado de Córdoba. Museo Británico, Add. 10.237, ff. 74. M. NIETO CUMPLIDO, Corpus.II, pp. 262-264.

47 Córdoba, 12 de noviembre de 1282. A.C.C., caj. P, n. 68. R.A.H., Ms. 9/5.436, ff. 315-316. Priego, 3 de diciembre de 1282. B.C.C., Ms. 125, f. 33. 
expresar la situación difícil por la que atravesó la sede cordobesa a la muerte de don Pascual y hasta la elección de Juan Fernández, que renunció a la sede ${ }^{48}$.

No parece, pues, descabellado poner en relación una larga y difícil vacación en la sede cordobesa con la queja presentada por los obispos al rey Fernando IV. Este, en el Ordenamiento de Prelados de Valladolid, 12 de agosto de 1295, reconoce que hubo abusos no sólo en la elección de obispos y prelados, sino también en la apropiación de las rentas episcopales sede vacante por la Corona o por los hombres poderosos ${ }^{49}$.

Pero la primera elección del cabildo catedralicio, a fin de salir de esta situación, resultó fallida. El maestrescuela Juan Fernández no aceptó su elección, a la que renunció ante el deán de Córdoba en Perusa, 15 de febrero de 1294, al decir de Linehan por posible ilegitimidad ${ }^{50}$. En consecuencia, hubo de procederse a una nueva elección, por vía de escrutinio, que recayó en la persona de don Gil Domínguez, arcediano de Riba de Sil en Astorga. Los delegados capitulares primero se dirigieron a recabar su consentimiento al Estudio de Bolonia, donde al decir de algún capitular se hallaba, si bien lo encontraron en San Juan de Pie de Puerto, donde le pidieron su aceptación, y finalmente en Pamplona obtuvieron su consentimiento en 30 de junio de 1294.

Para el 15 de noviembre de 1294 ya hacía algún tiempo que había tomado posesión de la sede, pues en esta fecha el arcediano de Pedroche, don Bernalt, mandó en su testamento dos sortijas al electo don Gil ${ }^{51}$. Al parecer también en esta fecha debió realizar algún acto en la curia pontificia, pues es la que ofrece Eubel para el electo Aegidius.

En Alcalá de Henares, 19 de diciembre de 1294, prestó la obediencia y el juramento al metropolitano de Toledo, seguramente a la vez que era consagrado por éste ${ }^{52}$.

En cuanto a su extracción social poco se sabe, excepto que es llamado «criado» por el rey Sancho IV ${ }^{53}$ y que, en efecto, debió graduarse en leyes en

\footnotetext{
48 «Cum propter vacationem diuturnam ecclesie pastoris solaciis destitute gravis in spiritualibus et temporalibus dispendia patiantur, conditores canonum, deliberatione provida, convenerunt quod ultra tres menses vacare non debeant ecclesie cathedrales. Recepta igitur per venerabilem virum $P$. decanum nostrum renuntiationem venerabilis viris Iohannis Ferrandi..., qui postulatus fuerat a nobis concorditer in ecclesie nostre episcopum et pastorem ...» B.N., Ms. 13.035, ff. 178-179.

${ }^{49}$ A.C.C., caj. M, n. 100. B.C.C., Ms. 125, ff. 14-15. M. ColmEIRO, Cortes de los antiguos reinos de León y de Castilla. I, pp.133-135. A. BENAVIDES, Memorias de don Fernando IV de Castilla. Madrid, 1860. T.II, pp. 33-35.

50 B.N., Ms. 13.035, ff. 178-179. P. LINEHAN, La Iglesia Española y el Papado en el siglo XIII. Salamanca, 1975, p. 227.

${ }^{51}$ Córdoba, 15 de noviembre de 1294. B.C.C., Ms. 125, ff. 128-129.

52 B.N., Ms. 13.035, f. 134.

53 Valladolid, 15 de noviembre de 1294. A.C.C., caj. Z, n. 274. B.C.C., Ms. 125, f. 28.
}

Episcopado Hispano

Hispania Sacra 54 (2002) 
Bolonia, siendo arcediano en Astorga, por lo que parece poder adscribírsele a una familia de hidalgos leoneses.

Otras noticias de su episcopado están constituidas por el ordenamiento, que hizo sobre los arrendamientos de posesiones de la Iglesia en 1297, a fin de salvaguardar su integridad y rentabilidad. También por un estatuto capitular sobre las injurias, que pudieran causarse unos capitulares a otros, en 1298, que perduró hasta su renovación por el obispo don Andrés en 1366.

El final de su episcopado es una incógnita. Gómez Bravo asegura que murió a finales de 1299, mientras que Eubel señala que en este año salió de la sede. Parece esto último lo más probable, ya que no parece haber dejado rastro alguno de aniversarios ni memorias en el Libro Verde, lo que también denotaría su desvinculación con la sociedad cordobesa. Debía haber sede vacante cuando el cabildo eligió como provisores del obispado al deán don Pedro de Ayllón y al canónigo Juan Martín, quienęs actuaron como tales el 19 de noviembre de $1299^{54}$.

\section{LOS OBISPOS DEL SIGLO XIV}

\section{DON FERNANDO GUTIÉRREZ (12 de junio de 1300 a 11 de abril de 1326).}

A pesar de la escasez de noticias, podemos decir que, tanto el dilatado episcopado de don Fernando Gutiérrez, como las circunstancias de toda índole, que se produjeron y su propia actividad en todos los campos configuran este primer cuarto del siglo XIV como decisivo para la Iglesia y la sociedad cordobesa.

El primer problema que afrontamos es la personalidad misma del obispo.

Para unos autores, se trata de don Fernando Gutiérrez de los Ríos, hijo segundo de don Gutierre Fernández (o Juan Gutiérrez) de los Ríos y de doña Leonor López de Haro y nieto del conquistador de Córdoba don Fernando Gutiérrez de los Ríos. Se trataría, además, del sucesor en la canonjía vacante por muerte de su tío, Pedro Alfonso de Haro, en 1288. También del sucesor del arcediano de Córdoba, que en la discutida elección capitular de 1300 fue electo obispo de Córdoba por mayoría, que renunció a su derecho en el papa y que Bonifacio VIII, en 12 de junio de 1300, designó como obispo de Córdoba, si

${ }^{54}$ A.C.C., caj. B, n. 304. 
bien encargando al arcediano de Baeza, también llamado Fernando, que le diera posesión del obispado ${ }^{55}$.

Por otra parte, está el tenor de la bula (no desconocida al parecer por Gómez Bravo, aunque la fecha en 2 de junio en vez de 12 de junio), donde claramente se dice que el papa, ante la renuncia de los elegidos en disputa, designa para obispo de Córdoba a maestre Fernando arcediano de Baeza ${ }^{56}$. Eubel añade que el arcediano de Córdoba fue electo de Calahorra también en esta fecha. Por lo demás, el arcediano de Baeza y electo de Córdoba será consagrado obispo en la curia pontificia por el obispo Ostiense don Nicolás poco despué $^{57}$. En 8 de septiembre de 1300 promete la fidelidad y respetos debidos al metropolitano de Toledo ${ }^{58}$.

En este caso habría que admitir, de un lado, que el electo de Calahorra, anteriormente arcediano de Córdoba, es el maestrescuela de Córdoba, documentado fehacientemente por las compras de bienes, que después donará pro anima al cabildo catedralicio. Se trataría de don Fernando González de Estrada, conocido únicamente como maestrescuela de Córdoba y obispo de Calahorra por los autores locales, hermano del que fue arzobispo de Sevilla, don Sancho González de Estrada.

De otra parte, hay que admitir que, si bien el arcediano de Baeza poco tenía que ver con la Iglesia de Córdoba, pues no consta que en ella fuera prebendado, ni que hiciera donación pro anima alguna a la misma, este maestro don Fernando tenía fuertes intereses en la ciudad y obispado de Córdoba. En consecuencia, bien pudieran tener razón los autores locales al adscribirle a la familia cordobesa de los Gutiérrez de los Ríos. En cuanto a su formación cultural, debió ser maestro, como correspondia en general a todos los que disfrutaban de alguna dignidad catedralicia, y seguramente en derecho o leyes, pues se le ve actuando como juez delegado antes y después de ser obispo de Córdoba.

Desde un primer momento se le ve tomar partido, si es que su familia no lo había tomado ya previamente, junto al alcalde de Córdoba, don Fernando Díaz Carrillo, señor de Santa Eufemia desde 1293, cuando como obispo engrandece la jurisdicción de la iglesia parroquial de Santa Eufemia y le confiere límites mayores que los primeros en 1301. Esto servirá de base para el señorío de don Fernando Díaz, una vez que consiga la confirmación del rey Alfonso XI en

\footnotetext{
55 Así los autores locales: J. Gómez Bravo, Catálogo.I, p. 285. R. RAMírez DE ARELLANO, Historia de Córdoba.IV, p. 81. T. MÁRQUEZ DE CASTRO, Compendio histórico y genealógico de los títulos de Castilla y señorios antiguos y modernos de la ciudad de Córdoba y su reino. Ed. y estudio por J.M. de Bernardo Ares. Córdoba, 1981, p. 76. La Casa de Cabrera en Córdoba, pp. 99,190 y 192.

5612 de junio de 1300. A.C.C., caj. M, n. 47. B.N., Ms. 13.035, ff. 180-181. A. BENAVIDES, Memorias.II, pp. 215-216. G. DIGARD, etc.: Les Registres de Boniface VIII, n. 3.634.

57 Ibidem, n. 4.155.

58 B.N., Ms. 13.035, f. 135.
}

Episcopado Hispano

Hispania Sacra 54 (2002) 
1319. En el partido de este Fernando Díaz estarían también los que se nombran en la Crónica del rey don Alfonso el Onceno como parciales del tutor infante don Juan Manuel en Córdoba, Pedro Díaz hermano de Fernando, Alfonso de Haro y Juan Ponce de Cabrera ${ }^{59}$.

En el partido contrario estaban los expulsados de la ciudad en 1320, el alcaide del alcázar y señor de Espejo, don Pay Arias de Castro, don Alfonso Fernández de Córdoba señor de Cañete desde 1293 y eventualmente alguacil mayor de Córdoba y su hijo Fernando Alfonso de Córdoba ${ }^{60}$.

Los enfrentamientos más directos del obispo con don Pay Arias de Castro se dieron con motivo de la creación del señorío de Espejo y la interpretación de la concesión pontificia de los diezmos prediales en 1311.

Los alborotos y enfrentamientos entre parcialidades de los caballeros cordobeses venían produciéndose desde el momento en el que los detentadores de oficios de nombramiento real querían hacerlos hereditarios y el proceso de oligarquización de la caballería se acentuaba. Consecuentemente, una parcialidad dominaría los cargos electivos en la ciudad, en la que se impuso seguramente en el reinado de Fernando IV y sobre todo en las primeras y segundas tutorías de Alfonso XI. La otra parcialidad acabará imponiéndose en la mayoría de edad de este rey.

Así cabe interpretar la noticia en la Crónica del rey don Fernando Cuarto $o^{61}$, donde se dice que hacia 1307-1310 el rey se dirigió a Córdoba

\begin{abstract}
«... por razón que avía y en la villa de Córdoba grand levantamiento del pueblo contra algunos de los caballeros más honrados de la villa e desque el rey llegó a la cibdad de Córdoba mandó saber los fechos de la villa, e desque los ovo sabido fizo grand justicia en aquellos que falló que eran merescedores, que fueron comienzo e acuciadores deste levantamiento del pueblo, ca desque la cibdad fuera de cristianos nunca tan grand levantamiento ovo commo aquel».
\end{abstract}

Aquí nos separamos claramente de la interpretación de Valdeón Baruque, que opone pueblo a caballeros, al igual que hace con la noticia de la Crónica de Alfonso $X I$ sobre la expresión «Et en este tiempo avía grand contienda entre el pueblo de Córdoba et los caballeros». En efecto, se trataba sí de pedir a doña María de Molina la elección de todos los oficios en lugar de la designación real. Pero por razón de que determinados caballeros dominaban las elecciones de la ciudad. Así se comprueba, que tras la expulsión de 1320, Pedro Alfonso

59 Crónica del rey don Alfonso el Onceno. B.A.E., T.LXVI, Madrid, 1953, cap. XXIV, p. 190. J. Gómez Bravo, Catálogo.I, p. 289. R. RamíreZ De ARellano, Historia de Córdoba.IV, p. 86.

60 Véase también M.C. QUINTANILLA RASO, Nobleza y señorios, pp. 31 y 33.

${ }^{61}$ Crónica del rey don Fernando Cuarto. B.A.E., T.LXVI. Madrid, 1953, p. 164. 
de Haro se había hecho con el castillo de Chillón, Pedro Díaz de Aguayo con Castro el Viejo y Juan Ponce con Cabra ${ }^{62}$.

La mayoría del rey Alfonso XI supuso el auge de la oligarquía de caballeros, que debían su oficio al rey, sobre la que había tratado de dominar, actuando sobre el principio electivo de los cargos, reconocido por el fuero de Fernando III. Por ello cabe pensar que, tanto el traslado del obispo don Fernando Gutiérrez a Cuenca, como la venida de don Gutierre Ruiz de Mesa desde la diócesis de Idanha en Portugal, sean obra de Alfonso XI.

Las parcialidades del momento se reflejaban en el seno del cabildo catedralicio. Aunque no debamos proyectar sobre el cabildo los enfrentamientos relatados, sin embargo se denuncian tales parcialidades en un documento de 1331, donde el cabildo catedralicio pide al obispo don Gutierre Ruiz de Mesa que le devuelva los bienes, que indebidamente tomó para sí el obispo don Fernando Gutiérrez ${ }^{63}$.

En efecto, y con esto entramos a tocar otros dos puntos de la actividad de nuestro obispo en Córdoba, don Fernando Gutiérrez se había apropiado de los siguientes bienes y rentas de la mesa capitular: el medio tercio pontifical de las iglesias de Aguilar y sus téminos y de las iglesias de La Rambla y La Rinconada; la mitad del heredamiento de La Rinconada; la mitad de la renta de las tiendas dadas pro anima por el rey Alfonso X; más la mitad de la renta de los baños, que están cerca de la Puerta de la Pescadería; más la mitad de los dos mil mrs. situados en la aduana a favor de la Iglesia. Todo esto ignorando la composición y trueque hechos entre las mesas episcopal y capitular de 8 de enero de 1264.

$\mathrm{Al}$ parecer este obispo pretendía continuar recuperando para la mitra los bienes y rentas que eventualmente le hubieran sido arrebatados. Al poco de entrar en su oficio episcopal, en 14 de diciembre de 1300, se personó en La Rinconada para expulsar a los labradores, que indebidamente tenían ocupadas las heredades eclesiásticas en esta aldea, especialmente las cuarenta yugadas del cortijo de los Tejedores dadas por el rey Fernando $\mathrm{III}^{64}$. Acto seguido se hizo dar, seguramente en préstamo, todo este heredamiento más la torre de Teresa Iñ́guez, por lo que en 1306 suscribió un compromiso con el cabildo

$62 \mathrm{~J}$. VALDEÓN BARUQUE, Los conflictos sociales en el reino de Castilla en los siglos XIV y XV. Madrid, 1979 (1 ed., 1975), pp. 73-75. Véase la respuesta de Alfonso XI al alcalde mayor de Córdoba, don Alfonso Fernández de Córdoba, de fecha en Escalona, 3 de mayo de 1328. R.A.H., Ms. 9/5.434, ff. 86-92. R. RAMíREZ DE ARELlANO, Historia de Córdoba.IV, pp. 90-92.

63 «Et porque a esse tiempo avíe muchos omnes buenos en la eglesia que avíen grant voluntad de seguir el talante del dicho obispo [don Fernando], e por esto no pudistes aver las dichas cartas, porque fueran encubiertas. Et después que el dicho obispo finó, dixistes que fisiérades mucho por las cobrar, e que las avíedes ya cobrado de algunos lugares do estaban encubiertamente...». Córdoba, 12 de noviembre de 1331. A.C.C., caj. N, nn. 29, 30, 31 y 51.

64 A.C.C., caj. V, n. 102. B.C.C., Ms. 125, ff. 118-119. R.A.H., Ms. 9/5.436, ff. 319-322.

Episcopado Hispano

Hispania Sacra 54 (2002) 
para dar a éste veinte cahíces de pan (mitad trigo, mitad cebada) por todo ello, entendiendo que al cabildo sólo pertenecía una parte de tal heredamiento ${ }^{65}$.

Continuando con esta política de recuperación de rentas eclesiásticas, nuestro obispo consiguió del rey Fernando IV, en 1305, excepción de maquila y cualquier pecho para el molino, que la iglesia catedral tenía en la huerta de don $\operatorname{Marcos}^{66}$. En el mismo año consigue normalizar, mediante concordia, los derechos que la Orden de Calatrava debía entregar a la Iglesia de Córdoba ${ }^{67}$. Esta es la primera concordia entre ambas instituciones, y parece haberse preocupado de restaurar las defensas de Castillo Anzur en 1306 y de poner en explotación su término en $1307^{68}$. Sentido similar puede tener, aparte del contenido de delimitación parroquial, la concordia con don Pay Arias de Castro sobre los diezmos prediales de Espejo de 1311.

Sin embargo, el cabildo catedralicio al menos una vez le contradijo, cuando en 1314 pretendió tomar la parte, que no le correspondía, de la ofrenda exequial de la mujer del señor de Aguilar ${ }^{69}$. Y es que las dificultades económicas del obispo debieron ser graves, a causa seguramente de su protagonismo en el tiempo de las tutorías, como recalca Linehan ${ }^{70}$.

Otro aspecto importante de su episcopado fue la cooperación, que ejerció en la cobranza de las tercias y décimas y cruzada otorgadas al rey Fernando IV y al infante don Pedro. Peter Linehan ha estudiado a la luz de los documentos vaticanos la percepción de las tercias y décima eclesiástica, que por tres años concedió el papa Clemente V a Fernando IV en 1309, para la guerra contra los moros de España. A lo cual puede añadirse la documentación conservada en Córdoba ${ }^{71}$.

65 Córdoba, 12 de enero de 1306. B.C.C., Ms. 125, f. 39

66 Valladolid, 7 de julio de 1305 . A.C.C., caj. Y, n. 260 . R.A.H., Ms. 9/5.436, ff. 322-323.

67 Córdoba, 13 de agosto de 1305. A.C.C., caj. Y, n. 28. B.C.C., Ms. 125, ff. 46-47. I. ORTEGA Y COTES, Bullarium... de Calatrava, pp. 202-204.

68 Córdoba, 12 de enero de 1306. B.C.C., Ms. 125, f. 39. Delimitación de términos de Lucena y Castillo Anzur con Benamejí en Córdoba, 7 de junio de 1307. A.C.C., caj. N, n. 7. B.C.C., Ms. 125, f 47. Delimitación que efectúa el alcalde mayor de Córdoba en 28 de noviembre de 1307.

${ }^{69}$ Córdoba, 24 de diciembre de 1314. B.C.C., Ms. 125, ff. 113-114.

$70 \mathrm{P}$. LINEHAN, «The Church, the economy and the reconquista in early fourteenthcentury Castile», en Revista Española de Teología 43 (1983), pp. 275-303, especialmente nota 80.

71 Ibidem. La documentación conservada en A.C.C., caj. H, n. 154 contiene copias notariales del nombramiento de subcolectores y subejecutores por el obispo de Córdoba en 7 de noviembre de 1313 y varias cartas de pago a Micer Oger de la Mar (Uclés, 26 de noviembre de 1314, Palencia, 6 de enero de 1315,7 de febrero de 1316 y otras sin fecha).

Tras el fracaso de anteriores colectores, el 1 de julio de 1312 el papa Clemente V designa nuevo colector a nuestro obispo don Fernando y al obispo de Ciudad Rodrigo. El nuevo equipo de colectores pontificios, que sustituían al arcediano de Játiva, ya había empezado a actuar hacia el verano de 1313 . Los dominios del rey Alfonso XI se dividieron en tres zonas. En la que comprendía el arzobispado de Toledo y los obispados de Sigüenza, Osma, Calahorra, Burgos, Palencia y Segovia el colector obispo 
Es de suponer que mantuvo una activa participación dentro de la Hermandad General de Andalucía y seguramente al lado de la parcialidad concejil y frente a los señores, que también pretendieron servirse de la misma para medrar en su provecho, como don Pay Arias de Castro en Córdoba.

de Córdoba había nombrado subcolectores, en 7 de noviembre de 1313, a su sobrino Juan Fernández, arcediano de Castro en Córdoba, y al compañero de la Iglesia de Córdoba, Juan González. Ambos salieron de Córdoba el 9 de octubre de 1313 y terminaron de recolectar lo que pudieron diecisiete meses y medio después, en 24 de abril de 1315.

Para entonces parece que habían entregado a Oger de la Mar, represetante de la compañía marsellesa arrendataria de la cámara pontificia por los 1.100 florines arrendados, $9.000 \mathrm{mrs}$. De los cuales, este Oger había devuelto al arcediano de Castro $600 \mathrm{mrs}$. por ciertos gastos. El obispo de Córdoba parece que dejaba a deber $5.000 \mathrm{mrs}$. por la parte que le tocaba en la décima. Para la zona de la Frontera (arzobispado de Sevilla y obispados de Córdoba, Cádiz, Jaén, Cuenca y Cartagena) el obispo de Córdoba designó subcolector a Gil Pérez canónigo de Córdoba y a Gil García compañero de la misma iglesia.

En 1317 el papa Juan XXII concedió al infante don Pedro, también por tres años, las tercias, décima eclesiástica y cruzada, si bien esta vez su colecturía se encargó directamente a los arzobispos de Toledo y Sevilla y al obispo de Córdoba. Los colectores debían entregarlo no a la cámara apostólica, sino directamente al infante y a Raimundo de Cardona (Aviñón, 25 de febrero de 1317. Varias bulas de la misma fecha. B.N., Ms. 13097, ff. 5, 11 y 18. J. MolLAT, Jean XXII (1316-1334). Lettres Communes, nn. 2.921, 2.922 y 2.925$)$. En el verano del mismo año los colectores ya habían nombrado a los subcolectores y establecido la forma de recaudar las tercias y décima eclesiástica (Villa Real, 7 de junio de 1317. B.N., Ms. 13.097, ff. 67-71. Córdoba, 16 de junio de 1317. B.N., Ms. 13.096, ff. 187-188. Villa Real, 17 de junio de 1317. B.N., Ms. 13097, ff. 56-58. Murcia, 19 de junio de 1317. Ibidem, ff. 60-63). También a finales del año el infante don Pedro, en carta dirgida a los colectores principales, quejándose de la exigüidad de la primera paga de las tercias y décima, designa a los hombres, que por él recogerán la segunda paga, a realizar en 31 de marzo de 1318. Entre éstos destacamos a los canónigos de Córdoba Lope Martínez (para el obispado de Córdoba), Gil García, que también era clérigo del tutor (para los obispados de Plasencia, Ciudad Rodrigo, Coria y Badajoz) y a Pedro Martínez (para los obispados de Salamanca, Zamora y León). (15 de diciembre de 1317. B.N., Ms. 13097, ff. 64-65).

En 1318 el papa Juan XXII unirá al equipo principal de colectores al arzobispo de Santiago de Compostela (Aviñón, 1 de junio de 1318. J. MOLLAT, Jean XXII, n. 7.328), seguramente porque hasta entonces Galicia no había cooperado en pago alguno. En el verano de 1318 también discuten el obispo de Córdoba y el arzobispo de Toledo el modo de mejorar las colectas, ante los apremios del infante don Pedro, quejoso de que las cantidades recibidas no se aproximaban a las expectativas y previsiones (Valladolid, 20 de junio de 1318. B.N., Ms. 13.097, ff. 66-67). Mientras, el papa encarga al arzobispo de Santiago y al obispo de Córdoba, que reciban en la empresa común de la guerra contra los moros al también infante y tutor don Juan (Aviñón, 25 de julio de 1318. J. MOLLAT, Jean XXII, n. 7.864) y manda a todos los colectores, que publiquen solemnemente la cruzada (Aviñón, 13 de agosto de 1318. Ibidem, n. 8.027. En Aviñón, 12 de diciembre de 1319, el papa Juan XXII manda a su nuncio Raimundo de Serra, que investigue el resultado de la colecta de la Cruzada. Ibidem, n. 12.046).

La desgraciada derrota de Elvira y la muerte de ambos infantes dará lugar al cierre en la percepción de las concesiones pontificias, a pesar de que en abril de 1320 en Córdoba pretendían seguir cobrándolas los subcolectores Francisco Gil, arcediano de Pedroche, y Beltrán Pérez canónigo (Córdoba, 5 de abril de 1320. A.C.C., caj., H, n. 104).

La última noticia de la participación del obispo de Córdoba en estas colecturías es de noviembre de 1320, cuando Juan XXII le manda entregar a Raimundo de Cardona la cantidad de 40.000 mrs., equivalentes a 2.200 florines, que el obispo aún adeudaba en las iglesias de Córdoba y de Jaén, sobre las tercias concedidas al infante don Pedro (Aviñón, 27 de noviembre de 1320. J. MolLAT, Jean XXII, n. 12.668).

Episcopado Hispano

Hispania Sacra 54 (2002) 
La cooperación militar del obispo don Fernando en las actividades fronterizas llevadas a cabo por el infante don Pedro (en 1315 en la cerca de Alicun y la toma de Cambil y Alhabar y en la campaña de $1316^{72}$ al menos), se debían, como la de sus antecesores (y en especial la del obispo don Gutierre Ruiz de Olea) al deber militar contraído por la tenencia y posesión señorial de castillos $\mathrm{y}$ villas fronterizos. Pero también se inscribían en la política concejil de la Hermandad y en las buenas relaciones con el infante.

A la muerte de los infantes don Pedro y don Juan (tutores de Alfonso XI) en la Vega de Granada en 1319, se sabe por una carta del obispo de Córdoba al arzobispo de Toledo, de 21 de julio (s.a.), que la Hermandad, pero en especial los grandes caballeros andaluces, se habían reunido en Palma del Río, acordando entre otros puntos no recibir a nadie por tutor en Andalucía, sino a quien toda Castilla y León reconocieran por tal. Además, acordaron una especial vigilancia y cuidado de villas y castillos ${ }^{73}$.

No obstante, el motivo central de la carta era prevenir al arzobispo de Toledo sobre los estragos, que había producido en Sevilla la revisión de las cuentas $\mathrm{y}$ actuaciones de los colectores de las concesiones pontificias anteriores en favor de Fernando IV y del infante don Pedro. También los males que estaba produciendo en Córdoba y los que se temía que produjera en Toledo. Esta revisión la realizaba, por encargo papal, el nuncio Raimundo de Serra ${ }^{74}$.

Por su posición contraria al predominio de los grandes señores, que iban surgiendo en Andalucía, el obispo don Fernando Gutiérrez debió pasar malos ratos, cuando don Pay Arias de Castro consigue los diezmos prediales de Espejo en 1309 del papa Clemente V. También cuando el papa Juan XXII le manda dispensar del impedimento de pública deshonestidad al hijo de don Pay Arias, Rodrigo, que se había casado con Teresa, hija del noble Juan Martínez de Argote, en 1319. Pero sus peores momentos los vivirá al final de su vida, cuando ya el papa lo había trasladado a la sede de Cuenca. Don Juan Ponce de Cabre-

72 L.M. RamíreZ DE LAS CASAS-DEZA, «Anales de la ciudad de Córdoba», en B.R.A.C., 59 (1948), pp. 36-37.

${ }_{73}$ Córdoba, 21 de julio (s.a.). B.N., Ms. 13.035, f. 164. M. NiETo CuMPLIDO, Orígenes del regionalismo andaluz (1235-1325). Córdoba, 1979, pp. 213-214. M. GRACIA FERNÁNDEZ, «La Hermandad General de Andalucía durante la minoría de Alfonso XI de Castilla», en H.I.D., 12 (1985), pp. 351-375.

${ }^{74}$ Aviñón, 12 de diciembre de 1319. J. MolLAT, Jean XXII, n. 12.046. El papa Juan XXII manda a sus nuncios Raimundo, Amelio y Raimundo Serra, que averigüen de los colectores designados por los arzobispos de Toledo y de Sevilla y por el obispo de Córdoba para la predicación de la cruzada y la colecta del subsidio, qué cantidades han podido recoger. Este Raimundo de Serra anteriormente había recibido el encargo de revisar la colecturía de la concesión pontificia a Fernando IV en 1309, por lo que estaba en Castilla en agosto de 1317 y continuaba su actividad fiscalizadora en 1320. Véase LINEHAN, P.: «The Church». 
ra, adelantado mayor de la Frontera, exigió a nuestro obispo la entrega de los castillos de Lucena y de Castillo Anzur. La negativa del obispo se saldó primero con su expulsión de la ciudad y la de algunos miembros del cabildo catedralicio. Después con su apresamiento, de manera que en 1 de junio de 1326, fecha de su designación para Cuenca, aún seguía preso. Finalmente pudo salir hacia su nueva sede, donde morirá al año siguiente ${ }^{75}$.

Participó también en la actividad política y de defensa eclesiástica, llevada a cabo por los obispos castellanos claramente desde 1282. No parece que asistiera personalmente al concilio provincial de Peñafiel de 1302, aunque en éste se le señala el último lugar a la derecha del arzobispo de Toledo, sino a través de algún representante suyo ${ }^{76}$. De cualquier modo, parece lógico que trasladase a su diócesis las disposicioens del mismo (aunque no nos queda noticia documentada de ello, ni la alusión que se hace al obispo Fernando en las Constituciones del Obispado de Córdoba del obispo don Iñigo Manrique permite pensar que se tratara de este obispo) en especial las referidas a la inmunidad y libertad de la Iglesia.

También estuvo presente por procurador en el llamado, por el padre Fita, concilio provincial de Alcalá de Henares, por un tal «domino Vela canonico» para nosotros desconocido, celebrado para examinar la cuestión de los Templarios a tratar en el posterior concilio general de Vienne ${ }^{77}$.

Su compromiso con los intereses de Andalucía, especialmente la defensa fronteriza, le hacía nadar entre dos aguas. De una parte, estaba con su arzobispo toledano, por lo que por un tiempo guardó el entredicho (impuesto por el papa Clemente V y llevado adelante por el metropolitano en Castilla y toda su provincia eclesiástica y que aún duraba después de la muerte de Fernando IV) en Córdoba, a causa de los excesos y apropiaciones del rey en el asunto de las tercias y décima concedida en 1309. De otra, la naciente Hermandad General

75 Aviñón, 7 de septiembre de 1319. J. Mollat, Jean XXII, n. 10.296. Aviñón, 1 de junio de 1326. Ibidem, nn. 24.541 y 24542.

76 J. SÁNCHEZ Herrero, Concilios Provinciales y Sínodos Toledanos de los siglos XIV y XV. La religiosidad cristiana del clero y pueblo. La Laguna, 1976, pp. 165-172. A pesar de que en la transcripción de las actas citadas no aparece el obispo de Córdoba, el autor afirma su presencia en p. 29. Por su parte afirma su presencia a través de procurador y citando los cánones de este concilio del cardenal Aguirre, J. GómEZ BRAvo, Catálogo.I p. 290.

77 F. FITA Y COLOME, Actas inéditas de siete concilios españoles celebrados desde el año 1282 hasta el de 1314. Madrid, 1882, pp. 26-27. Si bien, parece que la única relación que mantuvo en este asunto fue la comisión, que le hizo el papa Juan XXII, junto con el arzobispo de Santiago, sobre que indujera con eficacia a la reina doña María de Molina y al infante don Pedro a que restituyeran ciertos bienes de la orden del Temple, indebidamente detentados por éstos, porque habían sido reservados por Clemente V (Aviñón, 12 de agosto de 1318. J. Mollat, Jean XII, n. 8.338). Quizá también interviniera en el asunto de la villa de Palma, que por entonces pasó de los Templarios a la Corona (J. GóMEZ BRAvo, Catálogo, I, p. 287). 
de Andalucía, que había destinado o pensaba destinar para la defensa fronteriza las tercias, toda vez que esta práctica era habitual desde Alfonso X, le empujó a reconsiderar su postura y levantar el entredicho en la ciudad, al menos hasta que la cuestión fuera examinada nuevamente por el arzobispo. Así lo hace constar en carta de 5 de enero de 1313 al arzobispo toledano, intentando excusarse de acudir a una nueva convocatoria, que éste hacía de prelados (al decir de nuestro obispo, no se sabía bien si era concilio o simple deber de consejo), y que en todo caso le considerase representado por el obispo de Jaén, si fuere o por el sobrino de nuestro obispo (el canónigo Lope Martínez, que estaba estudiando en Salamanca) como preparación a la próxima convocatoria de las Cortes de Palencia ${ }^{78}$.

A pesar de la importancia que tuvo el concilio nacional de Valladolid de 1322, no sólo en el momento de su celebración, sino sobre todo con referencia al movimiento sinodal y conciliar castellano en el siglo XIV, tampoco tenemos noticias de que asistiera personalmente nuestro obispo, aunque debe suponerse la presencia de algún procurador suyo. Tampoco consta su presencia en el concilio provincial de Toledo de 1324.

Un último punto a examinar es su política de designación de capitulares de la Iglesia de Córdoba, así como la reforma de la red parroquial rural. Sobre lo primero ya se vio que tenía partidarios y detractores. Entre los partidarios hay que incluir, dede luego, a sus sobrinos el canónigo, arcediano de Castro y deán Juan Fernández (que será subcolector pontificio y acabará como obispo de Lugo) y Lope Martínez (que también será subcolector). También parece que deba incluirse a su vicario general el canónigo Francisco Gil.

En cuanto a la reestructuración de la red parroquial rural, parece confirmar la tendencia iniciada hacia la concentración de la población en torno a núcleos defensivos. Así la nueva delimitación de la iglesia de Santa Eufemia en 1301 y la de la nueva parroquial de Espejo, al parecer a costa de la desaparición de las iglesias de Cuevas de Carchena y Montefrío o al menos de un recorte drástico, y el aumento territorial de la de Castro del Río a partir de 1311. Sin embargo, no parece que en principio quepa decir lo mismo de la nueva parroquia de El Carpio, que aún en 1329-1344 coexistía con la de Alcocer.

En cuanto a sus colaboradores más próximos cabe citar a los vicarios simultáneos y sucesivos siguientes: don Juan González y Gil Pérez canónigos, Benito Pérez, Francisco Gil y Lope Martínez. Finalmente a su capellán Martín Pérez.

El final de su episcopado en Córdoba consiste en su traslado al obispado de Cuenca en 11 de abril de 1326. Equivocadamente, Gómez Bravo le da como difunto a principios de 1322 .

\footnotetext{
${ }^{78}$ Córdoba, 5 de enero de 1313. F. FITA Y COLOME, Actas inéditas, pp. 151-154.
} 
9. DON GUTIERRE RUIZ DE MESA (11 de Abri de 1326 a 8 de febrero de 1336).

El mismo día que el pontífice Juan XXII trasladaba a Cuenca a don Fernando Gutiérrez, trasladaba de Idanha en Portugal (de la provincia de Santiago de Compostela hasta que en 1394 pasa a la de Lisboa) a don Gutierre Ruiz de Mesa. En tales cambios puede verse la mano del rey Alfonso XI.

Según Eubel, este don Gutierre anteriormente había sido obispo de Jaén, desde 13 de febrero de 1317 (por designación papal tras de rechazar el cabildo catedralicio jiennense al electo don Lope López, arcediano de Jaén) hasta que en 1 de octubre de 1322 es designado obispo de Idanha ${ }^{79}$, y anteriormente deán de Córdoba.

Sin embargo, el mismo autor en Jaén le llama Gutierre Téllez y, en Córdoba, Gutierre Ruiz de Mesa. Parece que tomó de Jimena Jurado el apellido Téllez. Este, por su parte, ignora la procedencia de este obispo y lo hace natural de Soria, alimentado sin duda por la tradición de los enfrentamientos entre naturales de Jaén y adventicios de Soria en el seno del cabildo y a la hora de las elecciones episcopales. Además, le hace morir en 1322 y le da sepultura en la colegial de Ubeda ${ }^{80}$.

No obstante, parece claro que el deán de Córdoba don Gutierre es el mismo que como obispo en 1331 promete a su cabildo devolverle los bienes y rentas usurpados por su antecesor el obispo don Fernando Gutiérrez, pues él mismo como deán se lo recriminó a este obispo, y es reconocido como sobrino del difunto obispo de Córdoba don Fernando de Mesa. En cuanto a la formación cultural debía tener grados en leyes o en derecho canónico, pues ya siendo deán, en 1303 , aparece como juez ordinario por el obispo don Fernando Gutiérrez ${ }^{81}$.

Por su parte, Ramírez de Arellano, siguiendo a Gómez Bravo, fecha la muerte del obispo don Fernando Gutiérrez en 1322 y cree descubrir a un obispo intermedio entre don Fernando y don Gutierre, llamado don García ${ }^{82}$. Gómez Bravo se preguntaba qué habría sido del obispo don Gutierre, desde los años en los que fue deán de Córdoba hasta que aparece como obispo, suponiéndole gozar de alguna dignidad en otra iglesia.

En cuanto a su extracción social, nos dicen Gómez Bravo y el autor de la Casa de Cabrera en Córdoba, que era sobrino del difunto obispo de Córdoba, don Fernando de Mesa. El segundo añade que el conquistador de Córdoba Ruy

\footnotetext{
79 C. EUBEL, Hierarchia.I, pp. 209, 235 y 262.

${ }^{80}$ M. JiMENA JURADO, Catálogo de los obispos... de Jaén y anales eclesiásticos de este obispado. Madrid, 1654, p. 326.

81 Córdoba, 8 de septiembre de 1303. B.C.C., Ms. 125, f. 54.

82 R. RAMírez DE ARellano, Historia de Córdoba.IV, p. 87. 
Fernández de Mesa tuvo como hijo tercero al obispo difunto y como hijo cuarto a otro que le acompañó en la conquista, también llamado Ruy Fernández de Mesa, de quien don Gutierre Ruiz de Mesa fue hijo segundo. También es hermano de Fernando Ruiz y albacea de don Gonzalo Pérez de Córdoba, alcalde del rey en Córdoba. Su sobrino el canónigo Gutierre Ruiz, hace testamento en $1349^{83}$.

Cabe pensar, por tanto, que nuestro obispo iniciara su carrera eclesiástica con la ayuda directa de su tío. Pero no es un caso de nepotismo, ya que las noticias que hay de su sobrino son posteriores a la muerte del obispo don Fernando de Mesa: era canónigo en 30 de junio de 1294, arcediano de Pedroche en 14 de diciembre de 1300 y deán en 15 de abril de 1303. Debe suponérsele capellán real, tanto por su ascendencia familiar como por las dignidades desempeñadas.

En su episcopado asistió al principio del fin de los señoríos episcopales en Córdoba, por causa de las últimas y poderosas embestidas de las fuerzas benimerines y granadinas combinadas. En esto no se diferencia de otros muchos señoríos, que definitivamente cambiarán de titulares por esta causa. Por lo demás, este asunto le impidió mantener con su cabildo las felices relaciones de amistad y cooperación, que en principio se prometieran y aún en 1331 pretendieran continuar.

Aún disuelta la Hermandad General de Andalucía, la preocupación fundamental de los hombres e instituciones de la frontera era la custodia y defensa de las fortalezas, castillos y villas fronterizas, cuyo peligro era manifiesto después del desastre de Elvira de 1319. El concejo de Córdoba estaba preocupado, entre otros asuntos, por la situación defensiva de la villa y murallas de Lucena. El rey Alfonso XI, en su respuesta a varias consultas del concejo en 1328, dijo con respecto a este asunto:

«A lo que decides que embiase decir al obispo que vasteciese Lucena y que la labrase. A esto digo quel mandé mandé dar los tercinuelos para que con que lo labre et lo bastesca et sea guardado para mio servicio et vosotros non recibades mal nin danno por esta razón» ${ }^{84}$.

De esto puede deducirse, por un lado, que Castillo Anzur, que era episcopal, estaba en tenencia del señor de Aguilar, por cuya razón no preocupaba ahora al concejo de Córdoba, mientras que Lucena era posesión y tenencia del obispo, con deberes militares por ello.

${ }^{83}$ La casa de Cabrera en Córdoba. Córdoba, 1779, pp. 431-432. Valladolid, 17 de junio de 1314. B.C.C., Ms. 125, f. 37. Córdoba, 13 de junio de 1311. Ibidem, f. 133. Córdoba, 17 de julio de 1349. A.C.C., caj., L, n. 216.

84 Real sobre Escalona, 3 de mayo de 1328. A.M.C., Libro de Privilegios, ff. 39-42. R.A.H., Ms. 9/5.434, ff.86-92. Véase R. RAMíreZ DE ARELlANO, Historia de Córdoba.IV, pp. 91-93.

Episcopado Hispano Hispania Sacra 54 (2002) 
Precisamente por esto, como era general desde los tiempos de Alfonso X, el rey le daba las tercias reales del lugar, al menos, como a los demás tenentes $\mathrm{o}$ señores de fortalezas fronterizas. Sin embargo, las rentas que produjera Lucena, más las tercias, no eran suficientes para los gastos necesarios de su defensa, más aún cuando los más poderosos ataques de los granadinos se van a dar en los años 1329-1334, siendo especialemente duros los de 1333. El obispo hubo de echar mano de todos los recursos disponibles.

Así, es verdad que en 1331 promete devolver al cabildo los bienes y derechos usurpados por su antencesor, pero parece que no lo cumplirá, ni podía cumplirlo, sino que aún a su muerte dejará una deuda de $17.400 \mathrm{mrs}$. al cabildo por causa de Lucena. Más aún, el obispo, con asentimiento del rey Alfonso XI, hubo de dar en tenencia la villa de Lucena al maestre de Santiago don Vasco Rodríguez, quien en el verano de 1332 había invertido unos 50.000 mrs. para fortificar sus defensas. Esta inversión debía ser pagada por el obispo, si quería volver a recuperar la villa y aún continuar otros trabajos en las murallas. Por esta causa el cabildo catedralicio le compele por dos veces a que pague la deuda, antes de que le resulte imposible afrontar más gastos y pierda la Iglesia definitivamente este señorío. Acaso tenían presente que Castillo Anzur hacía poco que se perdiera por la misma razón ${ }^{85}$. Finalmente, el obispo debió pagar como pudo su deuda a la Orden de Santiago al año siguiente y recuperar la villa ${ }^{86}$.

Pero no acababan aquí sus problemas. En 1334 hubo de sufrir el secuestro de sus rentas por orden de Alfonso XI para mantenimiento de Lucena (que después de la tenencia de la Orden de Santiago había pasado a manos de Juan Pérez y después de Egas) así como también el cabildo catedralicio. Por ello el cabildo reclamó al rey la devolución de los $14.695 \mathrm{mrs}$., que le habían embargado injustamente, ya que Lucena era villa de la mesa episcopal únicamente ${ }^{87}$.

$\mathrm{Al}$ poco tiempo de la muerte del obispo don Gutierre, el cabildo catedralicio, antes de proceder a la elección de sucesor, se vio en la necesidad de otorgar un estatuto a jurar por todos, incluido el que fuera obispo electo, para guardar al instituto ciertos derechos usurpados o debidos. Entre otros, la deuda episcopal de $17.400 \mathrm{mrs}$. por la retenencia de Lucena ${ }^{88}$. El destino final de esta villa será pasar a señorío laico.

También nuestro obispo fue colector de las tercias, décima eclesiástica y cruzada, que concedió el papa Juan XXII a Alfonso XI en $1328^{89}$, junto con el

\footnotetext{
85 Córdoba, 25 de junio de 1332. A.C.C., caj. N, n. 9. Córdoba, 6 de agosto de 1332. Ibidem, n. 10.

${ }^{86}$ M. NIETO CUMPLIDO, «Aportación a la historia de Lucena, 1240-1366», en Lucena. Apuntes para su historia. Lucena, 1981, pp. 266-269.

${ }^{87}$ Sevilla, 12 de febrero de 1334. A.C.C., caj. I, n. 374. Córdoba, 8 de marzo de 1334. Ibidem.

88 Córdoba, 28 de febrero de 1336. B.C.C., Ms. 166, ff. 11-12. R.A.H., Ms. 9/5.436, ff. 323-327.

89 Aviñón, 13 de junio de 1328. D. MANSILla ReOYo, Documentación española del Archivo del Castel Sant Angelo. Roma, 1958, pp. 66-67.
} 
arzobispo de Sevilla y el obispo de Jaén, así como de la concesión por cuatro años de tercias y décima que hizo el papa Benedicto XII en $1335^{90}$.

Una decisión de carácter muy distinto es la que tomó el obispo don Gutierre Ruiz de Mesa en 1332, concediendo la iglesia de los Santos Mártires Acisclo y Victoria al cisterciense fr. Alfonso y quedando aquélla bajo la obediencia episcopal, porque tal monasterio permanecerá en esta situación ya a lo largo de la Edad Media ${ }^{91}$.

Entre sus colaboradores, además de la mayoría de los capitulares, cabe citar especialmente al tesorero Juan González, vicario general, y al capellán episcopal Domingo Gil.

La muerte de nuestro obispo debió ocurrir el 8 de febrero de 1336, como afirma Gómez Bravo, basado en el Libro Verde. Fue enterrado en la capilla de su tío, el obispo don Fernando de Mesa, siendo trasladado a la capilla de los Cinco Obispos en tiempos de don Leopoldo de Austria (1541-1557) ${ }^{92}$.

10. Don JuAn PÉrez de SAAVEdRA (20 de marzo de 1336 a julio de 1346).

Reunido el cabildo catedralicio para elegir obispo, en principio para el 9 de marzo, resultó elegido el 20 del mismo mes, por vía de compromisarios, don Juan Pérez de Saavedra, arcediano de Valderas en León y canónigo de Córdo$\mathrm{ba}^{93}$. El 2 de junio de 1336 promete obediencia al arzobispo de Toledo, don Jimeno de Luna, en Alcalá de Henares, seguramente al ser consagrado obispo. $\mathrm{Al}$ día siguiente el papa Benedicto XII manda conferir a favor de Diego Remigio de Guzmán el arcedianato y canonjía vacantes en León por la consagración de don Juan ${ }^{94}$.

Por lo demás, la adscripción a los Saavedra de Córdoba la hace el autor de la Casa de Cabrera en Córdoba, quizá en relación con el alcaide de Baena Alfonso Pérez de Saavedra, defensor de la villa en 1300. En cuanto a su formación intelectual, debió contar con grados universitarios, aunque desconocemos su especialidad. Su preocupación por promover a su clérigo, Diego Alfonso de Villamayor, bachiller en artes y enseñante de estas materias en Cór-

\footnotetext{
90 Aviñón, 12 de abril de 1335. G. DAUMET, Les Registres de Benoît XII, n. 2.315.

91 Córdoba, 10 de junio de 1332. A.C.C., caj. T, n. 151. B.C.C., Catálogo del siglo XVIII, Libro.I, n. 51.

92 J. Gómez Bravo, Catálogo.I, p. 296. B.C.C., Libro Verde, f. 116.

93 Córdoba, 20 de marzo de 1336. B.N., Ms. 13.035, ff. 150-156. Véase C. EUBEL, Hierarchia.I, p. 208, que da las mismas fechas.

94 Alcalá de Henares, 2 de junio de 1336. B.N., Ms. 13.035, f. 136. Aviñón, 3 de junio de 1336. G. DAUMET, Les Registres, n. 2.693.
} 
doba, a una notaría pontificia, demuestra su interés por la cultura. En su elección al episcopado sólo aparecen las expresiones obligadas: «literarum scientia, vita et moribus merito commendandum $\rangle^{95}$.

La característica del episcopado de don Juan Pérez es la reordenación de su Iglesia y de su diócesis a medida que las circunstancias se lo fueron permitiendo. En primer lugar, debe resaltarse la novedad, al menos según nuestras noticias, de la celebración de sínodo diocesano en Córdoba por vez primera, que bien pudieran haber sido dos.

Aunque no estuvo presente en el concilio provincial de Toledo de 19 de mayo de 1339, sí consta que acudieron sus procuradores, según las actas del mismo concilio ${ }^{96}$. Aquí baste señalar que constan algunas constituciones otorgadas por este obispo en las Constituciones del Obispado de Córdoba de don Iñigo Manrique.

También procedió a la reordenación de los bienes y posesiones de la mesa episcopal, fundamentalmente con el cambio de la villa de Lucena por una serie de propiedades cordobesas de doña Leonor de Guzmán. En ello no debe culparse de miopía ni al obispo ni a su cabildo, que le concedió su asentimiento, porque nadie está obligado a ser vidente de un futuro esplendoroso para Lucena a la distancia de más de cien años. Además, en 1366 aún el obispo y cabildo catedralicio pedirán al rey Enrique II la posesión de Lucena y de Castillo Anzur, por lo que parece que los contemporáneos no concedieron al trueque el valor definitivo que, sin embargo, adquirirá con el Trastámara.

El cambio se efectuó el 11 de agosto de 1342, es decir, después de la gran victoria del Salado. A pesar de todo, el mismo verano de 1342 los granadinos habían pasado a cuchillo a la población cordobesa de Palma del Río ¿Quién podía afirmar que El Salado fue una victoria total y que la frontera quedaba ya asegurada, incluso después de las ganancias de Alcalá la Real y del verano de 1341? Por lo demás, el rey Alfonso XI hubo de conceder fuero y franquicias a los repobladores de Lucena en $1344^{97}$. En estas circunstancias ningún contemporáneo podía decir que el cambio no era ventajoso para la Iglesia. Recuérdense los quebrantos económicos del episcopado anterior.

La permuta se realizó en el verano de 1342. A finales de julio el cabildo catedralicio, a petición de su obispo, tras madura consideración de lo gravoso,

${ }_{95}$ La Casa de Cabrera en Córdoba, p. 313. Gran Crónica de ... Alfonso XI.I, cap. III, p. 205.14 de julio de 1343. Bulario de Salamanca, T.I, p. 350.

96 «Igitur ed editarum constitutionum observationem summopere intendentes, presentibus... Cordubensis... procuratoribus in concilio congregatis, has edidimus constitutiones, quas iubemus in sinodis in nostra provincia proximo celebrandis publicari et inviolabiter observari». J. SÁNCHEZ HERRERO, Concilios Provinciales, p. 201.

97 Segovia, 12 de octubre de 1344. J. GÓMEZ Bravo, Catálogo.I, p. 299.

Episcopado Hispano

Hispania Sacra $54(2002)$ 
que resultaba para la Iglesia de Córdoba y para la mesa episcopal el mantenimiento de la posesión de Lucena, consiente en la permuta. Esta se realizará entre el obispo don Juan Pérez y el representante de doña Leonor de Guzmán con fecha de Tarifa, 11 de agosto de 1342. La confirmación regia es del día siguiente y la ulterior confirmación de doña Leonor es de Tarifa, 15 de agosto de $1342^{98}$. Los bienes que en Córdoba poseía doña Leonor de Guzmán, objeto de este cambio, eran: la Arrizafa, la huerta de Juan Gil, una huerta cerca de la Puerta de Baeza, un horno de pan cerca del cementerio de San Pedro, unas casas hacia la calle de Las Cabezas en la collación de Santa María y las aceñas de Aliburi en el Guadalquivir.

También hubo de proceder a la reorganización de las rentas eclesiásticas, a causa de los cambios producidos durante su episcopado en diversos señoríos. El señorío de Aguilar, que había revertido a la Corona, fue objeto de concordia con el rey Alfonso XI, por cuanto tocaba al patronato señorial sobre sus iglesias y a la percepción de los diezmos y otros derechos eclesiásticos. La concordia fue una reedición de la efectuada con el primer señor de Aguilar en 1260, ya que el rey confirma la misma a petición del obispo don Juan Pérez y de su cabildo catedralicio en $1346^{99}$.

De igual modo debió proceder con la Orden de Calatrava, una vez que ésta parece haber definido para este siglo sus posesiones en el obispado de Córdoba. En la práctica consistió en renovar el espíritu y la letra de la concordia de 1305 , inserta, y ciertas precisiones sobre la heredad de Pajares y sus aceñas, lo que se hace por la concordia de $1344^{100}$.

Con relación al pleito entre las mesas episcopal y capitular sobre los bienes y rentas usurpados por el obispo don Fernando Gutiérrez y aún retenidos, al parecer, por don Gutierre Ruiz de Mesa, parece que nuestro obispo finalmente dio satisfacción al cabildo catedralicio. Cumpliría así el juramento que, previo a su elección, había hecho en 1336, toda vez que su vicario general autorizó una copia de la reclamación capitular de 1331 en el año 1345. A pesar de lo cual o quizá por lo precario de la situación, los capitulares volverán a juramentarse antes de elegir obispo en 1346, para que tal devolución fuera satisfactoria ${ }^{101}$.

También procedió a la reordenación del cabildo catedralicio en lo tocante al culto y a la administración y otros pormenores, con el otorgamiento de varios

98 Real sobre Algeciras, 12 de agosto de 1342. A.M.C., Sección 2, Serie 29, doc. n. 5. B.N., Ms. 13.124, ff. 1-9. R.A.H., Ms. 9/5.436, ff. 721-728. B.C.C., Ms. 164, ff. 241-249. Catálogo del siglo XVIII, Libro N, nn. 11 y 12. Véase M. NIETO CUMPLIDO, «Aportación a la historia de Lucena», pp. 265-269.

99 Sevilla, 23 de abril de 1346. A.C.C., caj. S, ns. 6 y 96. B.C.C., Ms. 125, ff. 69-70.

100 A.C.C., caj. Y, n. 28. I. ORTEGA Y COTES, Bullarium... de Calatrava, pp. 202-204.

101 Córdoba, 8 de agosto de 1345. J. GómeZ Bravo, Catálogo.I, p. 299. Córdoba, 26 de julio de 1346. A.C.C., caj. N, n. 247. 
estatutos. En este clima de necesaria reordenación cabe pensar que también procediera a una reorganización de varias parroquias rurales, especialmente de las que podían ser consideradas ya como despoblados, aunque las noticias ciertas sobre este asunto son de años posteriores.

Por lo demás, colaboró con el rey Alfonso XI en varios asuntos fundamentalmente en la percepción de la décima, tercias y cruzada concedida por tres años por el papa Benedicto XII en 1340. También en el préstamo de mil cahíces de cebada y doscientos de trigo que obispo y cabildo catedralicio hicieron a Alfonso XI en el primer año del cerco de Algeciras. Seguramente nuestro obispo había sido clérigo real ${ }^{102}$.

Su muerte se produjo en el mes de julio de 1346, según Gómez Bravo, antes del día 26, cuando ya se reunió el cabildo catedralicio para tratar sobre el asunto de los bienes y rentas de la mesa capitular, que indebidamente habían pasado a la mesa episcopal.

11. Don Fernando NuÑEZ CABRERA (11 de diciembre de 1346 a 15 de febrero de 1350).

Era arcediano de Córdoba, anteriormente canónigo y maestrescuela, cuando el cabildo catedralicio se juramentó para cumplir y hacer cumplir la devolución de los bienes y rentas de la mesa capitular, sustraidos por el obispo don Fernando Gutiérrez, en 26 de julio de 1346, al poco de la muerte del obispo don Juan Pérez.

La elección de su persona para obispo de Córdoba debió realizarse en 11 de diciembre de 1346, según la cronología que ofrece Eubel. El lapso de tiempo entre la fecha del juramento de los capitulares en julio y el mes de diciembre, más que fuera confirmado y consagrado por el papa Clemente VI, más el endeudamiento que por esta y otras causas hubo de soportar inducen a pensar que tal vez fuera rechazada su elección en Toledo. También que necesitara pasar por la curia pontificia, en la que gestionaría todos los asuntos pendientes. En 7 de enero de 1347 obtenía permiso pontificio para endeudarse por un valor de 1.500 florines $^{103}$.

102 Aviñón, 7 de marzo de 1340. D. MANSILla ReOYo, Documentación española, p. 72 . De 18 de octubre de 1340 es un mandamiento del concejo de la ciudad de Sevilla para percibir décimas en el obispado de Córdoba a cuenta de un anterior empréstito concejil a Alfonso XI. A.C.C., caj. H, n. 60. Sevilla, 27 de abril de 1346. R.A.H., Ms. 9/5.436, ff. 327-328. A.C.C., caj. P, n. 246. Concesión del arcedianato de Valderas, vacante por la promoción de don Juan Pérez al episcopado, a favor del clérigo real Fernando García de Fontanella. 27 de enero de 1338. G. DAUMET, Les Registres de Benoît XII, n. 5.313.

${ }^{103}$ E DepreZ, y G. Mollat, Clemente VI (1342-1352), n. 1.293.

Episcopado Hispano

Hispania Sacra 54 (2002) 
En cuanto a su extracción social, dice Gómez Bravo que era hijo de Domingo Muñoz y de María Cabrera. En el Libro Verde aparece esta doña María Cabrera como madre de nuestro obispo. Por su parte, el autor de la Casa de Cabrera en Córdoba afirma que era pariente muy próximo de don Pedro Cabrera (señor de la casa de Torres Cabrera, muerto en 1358 por orden de Pedro I) y de don Juan Ponce Cabrera (adelantado mayor de la frontera y fundador de la capilla de Santiago de la catedral de Córdoba), así como tío de su sucesor en el episcopado, don Martín Jiménez de Argote, y de María Alfonso de Castro, hija primera de don Juan Arias de la Reguera (quinto señor de Espejo, el que compró al cabildo catedralicio su heredad de Cuevas de Carchena, lindera con el señorío y posesiones de Juan Arias) ${ }^{104}$.

Por lo demás nuestro obispo, en su testamento, otorgado en Córdoba a 28 de enero de $1350^{105}$, se declara padre de un tal Pedro, habido en María Fernández. A este Pedro manda en herencia la cașa de Cascajar (compuesta por viñas, huertas, aceñas, heredamientos y tierras a ambos lados del Guadalquivir) y que en lo sucesivo pase tal casa en herencia a los hijos de éste o, en su defecto, al cabildo catedralicio. También se declara hermano de Gonzalo Núñez, ya difunto, de quien obtuvo ciertos bienes, que lega a los hijos de éste, sus sobrinos, o, en su defecto, a Pedro hijo del obispo. Igualmente se declara hermano de Elvira Núñez. En cuanto a su formación cultural, sabemos que fue maestrescuela de Córdoba, aunque desconocemos su especialidad.

Su actuación eclesiástica parece continuación de la política de reordenación de su antecesor. Posiblemente celebró algún sínodo diocesano y el nombre del obispo don Fernando, como autor de ciertas constituciones, que aparecen en las sinodales refundidas por el obispo don Iñigo Manrique, corresponde al obispo de quien ahora tratamos. Asistió por medio de procurador al concilio provincial celebrado por el arzobispo de Toledo don Gil Alvarez de Albornoz en Alcalá de Henares de 24 de abril de $1347^{106}$. En este concilio se retoman las disposiciones sobre la inmunidad y libertad eclesiástica del concilio de Valladolid de 1322. Este puede ser el motivo de la visita que emprende en su obispado en Otoño de 1349, según denota un estatuto capitular, que mandaba tener por presentes a los miembros del cabildo catedralicio, que acompañen al obispo en sus visitas pastorales ${ }^{107}$.

104 J. Gómez Bravo, Catálogo.I, p. 302. B.C.C., Libro Verde, f. 93. La Casa de Cabrera en Córdoba, pp. 119 y 386. Según A. de Morales era hijo segundo de Juan Ponce Cabrera, segundo señor de Torre Arias o Torres Cabrera y rico hombre, y de Inés Enríquez de Toledo. Morales, A.: Historia y nobiliario de Córdoba. B.N., Ms. 3.269, f. 396.

105 A.C.C., caj. L, n. 237.

106 J. SÁnChez Herrero, Concilios Provinciales, p. 213. J. Gómez Bravo, Catálogo.I, p. 302.

10721 de octubre de 1349. B.C.C., Ms. 166, f. 49. 
Parece que este obispo entregó de su mesa episcopal los bienes y rentas reclamados por la mesa capitular, ya que no se vuelve a tener noticias de juramentaciones de capitulares para obtener esta devolución. También a fines de 1347 procedió, a petición de los clérigos de la ciudad y del obispado, a un reparto más equitativo de las contribuciones del entero estado eclesiástico cordobés en los pechos y servicios comunes. En adelante, del monto total, dividido en doce partes, las seis corresponderán al obispo y su cabildo catedralicio y las otras seis al resto de la clerecía. También debió proceder al menos a una visita pastoral de su obispado a finales de su episcopado ${ }^{108}$.

Además del testamento ya dicho, otorgó un codicilo la víspera de su muerte, el 14 de febrero de 1350. En sus mandas se recogía la forma de pagar las deudas contraidas en la curia papal, mandando 6.000 florines (unos 31.000 mrs.) sobre las rentas episcopales de cuatro años, a razón de 1.500 florines por año. También constan sus mandas piadosas ${ }^{109}$. Murió el 15 de febrero y fue sepultado en su capilla de San Ildefonso de la catedral.

Entre sus colaboradores hemos de anotar al maestrescuela Pedro García y a Ferrán Alvarez, vicarios generales.

12. Don MARTÍN JimÉNEZ DE ARGOTE (21 de mayo de 1350 a 14 de diciembre de 1362).

Según los autores que tratan sobre este obispo, fue elegido por el cabildo catedralicio, aunque no hay documentación al respecto, si bien todas las apariencias lo avalan. Así el corto tiempo desde la muerte de su antecesor hasta el momento en el que don Martín es ya electo y la prestación de obediencia al metropolitano de Toledo don Gil en Tarragona, 4 de julio de $1350^{110}$.

Anteriormente había sido canónigo, tesorero y, según Gómez Bravo, chantre al ser elegido por el cabildo. Sin embargo, Eubel afirma que era arcediano de Campos en Palencia, que es lo más probable, pudiendo tratarse de un acaparador de beneficios o más posiblemente que hubiera permutado la chantría por el arcedianato.

En cuanto a su extracción social, Gómez Bravo y Márquez de Castro, basándose en Pellicer, afirman que era hijo de Juan Martínez de Argote y de Mayor Fernández de Témez. El mismo obispo se declara sobrino de su antecesor,

\footnotetext{
108 Córdoba, 27 de diciembre de 1347. A.C.C., caj. H, n. 141. Córdoba, 21 de octubre de 1349. B.C.C., Ms. 166, f. 49.

${ }^{109}$ A.C.C., caj. N, n. 247 y caj. L, n. 238. B.C.C., Libro Verde, ff. 111-112. J. GómEz BRAVo, Catálogo.I, p. 303.

110 B.N., Ms. 13.035, f. 137.
}

Episcopado Hispano

Hispania Sacra 54 (2002) 
don Fernando Núñez Cabrera ${ }^{111}$. Fue enterrado junto a éste en la capilla de San Ildefonso de la catedral. Por lo demás, hemos de suponerle la posesión de algún grado universitario, aunque desconocemos su especialidad.

Se hizo cargo de las deudas de su tío y posiblemente por intermedio del prestamista judío cordobés don Zag Aben Hamías. Esta debió ser la razón de que le donara, en nombre de la Iglesia de Córdoba y por el tiempo de la vida de don Zag, «por muchos serviçios que fesistes e fasedes de cada día a nos e a la nuestra yglesia», todo el diezmo que debían dar los judíos de la ciudad a la Iglesia, en $1356^{112}$.

En cuanto a la reordenación de la percepción de las rentas eclesiásticas y de su propia mesa afrontó dos problemas. De una parte, asegurarse la percepción de las rentas decimales arrendadas, que desde hacía algún tiempo los arrendadores procuraban evitar con subterfugios y apoyados por la expansión de la jurisdicción concejil. Esta pretendía extenderse a todo tipo de contratos, como lo muestra la carta del rey Pedro I a las autoridades de Córdoba en $1350^{113}$, entre otros ejemplos que puede ponerse. También estableció una concordia con el nuevo señor de Palma del Río, el almirante Egidio Bocanegra, sobre el diezmo del almojarifazgo de esta villa, que desde 1254 pertenecía a la Iglesia de Córdoba. Por la misma los señores de Palma pagarán anualmente $300 \mathrm{mrs}$., cantidad en la que se valoraba tal diezmo ${ }^{114}$.

De otra parte, logró liberar a su mesa episcopal del pago de cualquier yantar, toda vez que ya no poseía, al menos de facto, señorío jurisdiccional alguno. Ya en 1352 consigue del rey Pedro I, con acuerdo de los de su Audiencia, un mandamiento a su despensero mayor, Gómez Pérez, y al de la reina, Lope Sánchez, para que no demanden yantar ninguno a la Iglesia de Córdoba por no poseer vasallos. Pero aún debe reiterar sus recursos al rey, quien manda en 1357 a sus despenseros que devuelvan a la Iglesia las prendas, que indebidamente tomaron en concepto de yantares debidos, pues la Iglesia no tiene vasallos desde que hiciera la permuta de la villa de Lucena, reiterado además el mismo año, citando el dictamen de los oidores de su Audiencia. Finalmente, el rey aún debe mandar en 1360 al jurado cordobés, Aparicio Rodríguez, que no demande yantar alguno a la Iglesia de Córdoba, no obstante sus cartas anterio-

111 J. Gómez Bravo, Catálogo.I, p. 304. T. MÁRQUeZ DE CASTRO, Compendio histórico y genealógico de los títulos de Castilla, p. 96. Ecija, 29 de mayo de 1359. J. GómEZ BRAvo, Catálogo.I, p. 304.

112 Real sobre Palenzuela, 7 de febrero de 1356. A.C.C., caj. P, n. 69.

113 Sevilla, 4 de octubre de 1350. A.C.C., caj. P, n. 219.

114 Córdoba, 21 de marzo de 1351. A.C.C., caj. Z, n. 158. 
res, en las que disponía lo contrario ${ }^{115}$. Las relaciones de nuestro obispo con el rey don Pedro, en cuanto que miembro del linaje de los Cabrera, debieron ser tensas, puesto que en 1358 este rey hizo matar a don Pedro Cabrera, señor de Torres Cabrera ${ }^{116}$

La muerte de nuestro obispo debió ocurrir poco antes del 14 de diciembre de 1362, cuando ya había sede vacante, según Gómez Bravo. Entre los colaboradores del obispo don Martín anotamos al vicario Martín Fernández.

13. DON ANDRÉS PÉREZ NAVARRo (22 de marzo de 1363 a 14 de septiembre de 1372).

No sabemos si este obispo fue elegido por el cabildo catedralicio de Córdoba o promovido directamente por el papa Urbano $\mathrm{V}$, dada la documentación conocida. Debió producirse una elección discutida, es decir no unánime, en la que el cabildo catedralicio se pronunciaría dividido por el candidato «petrista» y el papa elegiría o confirmaría al electo mayoritariamente, don Andrés Pérez Navarro, deán de Sevilla. La confirmación o promoción papal debió efectuarse en 22 de marzo de 1363, según la cronología ofrecida por Eubel. Es probable que desde este tiempo y hasta su consagración, hacia el 18 de agosto de 1363, estuviera en la corte pontificia de Aviñón, procurando los intereses de su elección. La expresión pontificia de esta última fecha referida a nuestro obispo es, a nuestro parecer, ambigua: «... dilectus filius Andreas, electus Cordubensis, tempore promotionis per nos factae de ipso ad Cordubensem ecclesiam tunc vacantem.... ${ }^{117}$.

La vacante de la sede cordobesa debió ser azarosa, a causa de las circunstancias del reinado de Pedro I y de la división interna de la oligarquía dirigente en el reino y obispado de Córdoba, que se refleja en el interior del cabildo catedralicio. No puede decirse que el tiempo transcurrido entre la muerte de su antecesor y el de la primera noticia de su elección sea excesivamente largo, pues debe pensarse que la elección capitular se efectuara en el plazo de tres meses, que el derecho canónico concedía a los cabildos catedralicios para ejercer su derecho electoral. Además, hasta llegar las causas a la corte pontificia también se exigía tiempo y, al parecer, ya se había decidido el 22 de marzo de

\footnotetext{
115 Córdoba, 10 de enero de 1352. R.A.H., Ms. 9/5.436, f. 331. Córdoba, 10 de enero de 1357. A.C.C., caj. N, n. 221. Sevilla, 18 de septiembre de 1357. Ibidem, n. 222. R.A.H., Ms. 9/5.436, ff. 329-331. Sevilla, 30 de enero de 1360. A.C.C., caj. N, n. 224.

116 Casa de Cabrera en Córdoba, p. 119.

117 V. BELTRÁN DE HEREDIA, Bulario de la Universidad de Salamanca (1219-1549). T.I. Salamanca, 1966, p. 389.
}

Episcopado Hispano

Hispania Sacra 54 (2002) 
1363. Sin embargo, sí puede decirse que el tiempo transcurrido entre su elección y posible consagración en agosto de 1363 y su toma de posesión del obispado, en 20 de enero de 1364 sea excesivo y por tanto indicador de dificultades en la sede vacante.

Según la carta-respuesta del rey Enrique II en 1366, toda la culpa fue de Pedro I, que secuestró los libros y bienes y rentas del obispo difunto. Sin embargo, no debe olvidarse el carácter propagandístico de la documentación emanada de la corte de Enrique II, especialmente en este año, que no se recata en tildar de tirano y falso rey a Pedro I. Por otra parte, esta interpretación parece contradecir la realidad de la filiación «petrista» del electo don Andrés.

Debe por tanto suponerse una división interna en el cabildo catedralicio y una oposición activa en la facción perdedora en la elección para con la entrada del nuevo obispo, así como una administración de la sede vacante en manos de los perdedores, pero allegados al obispo difunto. Estos se vieron perseguidos por los partidarios «petristas» antes de la muerte del obispo don Martín, siendo el episodio culminante la muerte de don Pedro Cabrera en 1358 por orden del rey Pedro I. Por su parte, el vicario general del obispado, sede vacante, fue el canónigo Ruy Sánchez, quien se negó a prestar la obediencia debida al nuevo obispo y seguramente quien encabeza la oposición decidida al mismo.

Según Ortíz de Zúñiga, don Andrés Pérez pertenecía al linaje sevillano de los Monsalve, partidarios del rey Pedro I y favorecidos por éste, siendo nieto de María Alfonso ${ }^{118}$. Esto nos da noticia sobre la extracción social de este obispo. Al igual que sus antecesores, pertenece a una familia de la oligarquía ciudadana, en este caso de Sevilla, núcleo principal de apoyo a Pedro I en Andalucía por estas fechas. Pero también hace pensar en su conexión con otros Alfonso de Córdoba, en especial con el arcediano de Córdoba, Diego Alfonso (muerto en 1374 por el deán Antón Martín, al decir de éste por orden de Enrique II), que llevaran adelante la candidatura del nuevo obispo.

La toma de posesión del obispado fue, como adelantamos, el sábado 20 de enero de 1364, cuando el obispo don Andrés Pérez entró en la ciudad, fue esperado en la Puerta del Perdón de la catedral por el cabildo catedralicio y clero de su iglesia, el clero parroquial de la ciudad con sus cruces procesionales y el clero de las comunidades religiosas. Con ellos entró a la catedral y finalmente tomó posesión de la sede en el coro de la capilla de San Clemente, procediendo a jurar los estatutos, ordenanzas y costumbres de la Iglesia de Córdoba y después recibir la obediencia de los capitulares, según el Libro de las Tablas, «salvo Ruy Sánchez canónigo, que salió de la villa e lo non quiso facer» ${ }^{119}$.

118 D. ORTIZ DE ZÚÑIGA, Anales, año 1409, cap. 5, p. 182 y año 1368, cap. 4, p. 177.

119 B.C.C., Ms. 125, f. 155. J. GómEZ BRAVO, Catálogo.I, p. 308. 
La postura decidida de nuestro obispo en favor de la causa del rey Pedro I le valió el embargo de sus posesiones y rentas, personales y eclesiásticas, por parte del rey Enrique II. No obstante, finalmente se llegó a cierta reconciliación en 1371, por la que le fueron devueltos todos sus bienes y derechos. Estos habían sido concedidos por el rey a micer León capitán y a otros señores y caballeros, hasta que por su alvalá de 2 de junio de 1371 manda que le sean devueltos. La causa de la privación de sus bienes alegada era «por quanto el dicho obispo sse ffue al rey de Portogal aviendo nos guerra con él». Entre otros bienes que recupera se halla una casa mesón, sita en la collación de San Andrés, con fecha de Córdoba 22 de julio de 1371, que antes, en 1365, había comprado en pública almoneda su mayordomo y clérigo Pascual Martínez, y que constituirá su donación pro anima al cabildo catedralicio ${ }^{120}$.

Esta postura «petrista» explica, de un lado, el que definitivamente la mesa episcopal pierda Lucena y Castillo Anzur, cuyo señorío había sido reivindicado por don Andrés con gran habilidad en carta dirigida a Enrique II en 1366, pero con no menor habilidad el rey respondió que ya proveería sobre el asunto. Así fue que Castillo Anzur quedó definitivamente integrado en el señorío de Aguilar y que Lucena se diera en señorío a Juan Martínez de Argote en 15 de abril de 1371. La reconciliación del obispo con el rey sólo sirvió para que aquél recuperara sus bienes patrimoniales y episcopales y su Iglesia viera una vez más confirmados sus privilegios en 29 de diciembre de 1371.

Se aludió anteriormente a la carta-respuesta del rey Enrique II, de fecha de Sevilla, 28 de junio de 1366, es decir, del año en el que el Trastámara se declaró rey. Los puntos que contenía la misma versaban sobre el traslado de los restos del rey Fernando IV a la catedral de Córdoba. La devolución ya comentada de los señoríos de Lucena y Castillo Anzur a la Iglesia cordobesa. La confirmación de los privilegios y usos de la misma Iglesia. La recuperación de los libros de cuentas, bienes y rentas de la sede embargados, según el documento, por orden de Pedro I (lo que es más probable pues era práctica habitual de los reyes prolongar las vacantes y usufructuar mientras esas rentas). Y la recuperación del empréstito forzoso de la Iglesia cordobesa a Pedro I en 1365, consistente en 400 cahíces de trigo pagados a un precio abusivamente bajo, trigo que sin embargo permanecía aún en su mayor parte en las casas de los «petristas» cordobeses.

No se puede decir que el rey Enrique II fuera dadivoso en sus respuestas, pues en lo único que de cerca le podía tocar, la devolución del empréstito (ya

120 Córdoba, 30 de octubre de 1365. A.C.C., caj. D, n. 441. El alvalá regio, mandando devolver los bienes al obispo, es de 2 de junio de 1371 y está incorporado en la toma de posesión de la casamesón de Córdoba, 22 de julio de 1371. A.C.C., caj. D, n. 465. Véase R. RAMírEZ DE ARELlanO, Historia de Córdoba. IV, pp. 133-134.

Episcopado Hispano

Hispania Sacra 54 (2002) 
vimos el caso de los señoríos) dispone que siga en sus lugares para socorro de los castillos fronterizos y que se les pague a $4 \mathrm{mrs}$. la fanega. Sí consigue, sin embargo, el obispo poder poner directamente en su iglesia un escribano para las rentas decimales, que en tiempos del obispo don Martín Jiménez de Argote el rey Pedro I había retirado, arrogándose este rey la potestad de nombrarlo directamente ${ }^{121}$.

A semejanza de su antecesor don Fernando Núñez Cabrera, el obispo don Andrés hará donación de su heredad de Quintos en Sevilla a sus hijos Alfonso, Alvaro, Isabel y Juana en 15 de junio de 1367. Esto con la condición de que, si el cabildo catedralicio sevillano resarcía a sus herederos con la cantidad de $30.000 \mathrm{mrs}$., tal heredad pasaría a propiedad de este cabildo, como finalmente ocurrirá, tomándose la posesión de la misma en $1404^{122}$.

De su episcopado queda noticia de al menos una visita pastoral en 1366. También de que en 1371 le tocó pagar al clero cordobés un subsidio de 1.890 mrs. para subvenir a los gastos del cardenal legado Bernardo. Entre sus ayudantes más próximos hay que anotar como vicarios generales a don Pedro Alfonso, arcediano de Castro y clérigo real, y Fernando Rodríguez tesorero, y como su clérigo mayordomo a Pascual Martínez. Su muerte ocurrió el 14 de septiembre de $1372^{123}$.

14. DON AlFonso DE VARGAS (11 de noviembre de 1372 a 7 de enero de 1379).

Don Alfonso de Vargas fue obispo de Córdoba, provisto por el papa Gregorio XI en 11 de noviembre de 1372, según Eubel. Fue anteriormente obispo de Avila, desde 21 de febrero de 1371, y aún antes arcediano de Toledo. Gómez Bravo confunde dos veces a nuestro obispo. En primer lugar, con el obispo de Cartagena, don Alfonso de Vargas, a quien hace venir a Córdoba. En segundo lugar, con el arzobispo de Sevilla homónimo y muerto en febrero de 1378,

${ }^{121}$ Sevilla, 28 de junio de 1366. A.C.C., caj. N, n. 157. Ibidem, caj. Z, ns. 49 y 51. R.A.H., Ms. 9/5.436, ff. 331-336. No obstante la pérdida definitiva de los señoríos episcopales de Lucena y Casti1lo Anzur, el infante don Juan debe mandar a sus depenseros y a las autoridades de Córdoba, que no demanden los $600 \mathrm{mrs}$. en concepto de yantares, debidos al infante heredero, ni otro yantar alguno, según el juicio emitido por los oidores de la Audiencia, por no poseer la Iglesia señorío alguno. Córdoba, 16 de abril de 1374. A.C.C., caj. N, n. 223.

122 I. MONTES ROMERO-CAMACHO, Permanencias y transformaciones del mundo rural sevillano en la Baja Edad Media: propiedades y rentas territoriales del cabildo de la catedral de Sevilla. Sevilla, 1986. Tesis inédita, p. 210.

123 Córdoba, 14 de octubre de 1366. B.C.C., Ms. 166, f. 47. Cuenca, 14 de noviembre de 1371. A.C.C., caj. H, n. 173. B.C.C., Libro Verde, f. 35. 
cuya noticia equivocada recoge Eubel ${ }^{124}$. En cuanto a la provisión pontificia de este toledano, cabe pensar en una precisa petición del rey Enrique II. Aunque suponemos su graduación universitaria, desconocemos en qué especialidad.

$\mathrm{Su}$ episcopado afrontó la reordenación en profundidad de la diócesis, tras los desastres y crisis acumulados a lo largo del siglo XIV y sus consecuencias en la vida eclesiástica. No consta que realizara sínodo diocesano, posiblemente en paralelo con la falta de actividad conciliar y sinodal en la metrópoli toledana, aunque debe suponerse que visitara su obispado ${ }^{125}$.

Sin embargo, su actividad se centró en un amplio espectro de necesidades urgentes: el culto y las rentas de la catedral y del cabildo catedralicio; las rentas decimales de la Iglesia; la reorganización de las parroquias rurales, que más habían sufrido la erosión de pobladores; el enfrentamietno con la nueva y ascendente nobleza y la oligarquía concejil; sin descontar algún enfrentamiento con el cabildo catedralicio.

La reordenación comenzó por su propia casa, es decir la catedral. Aquí se enfrentó abiertamente con el cabildo, al pretender imponer un derecho episcopal inusual en Córdoba sobre los miembros del cabildo, como era el pago de la luctuosa o mañería. El conflicto se sustanció ante el juez pontificio Sancho Martínez, deán de Jaén. Este sentencia en 1374, que el obispo de Córdoba no tiene derecho alguno a tomar mula o vaso de plata con motivo de la muerte de persona (dignidad) o clérigo alguno beneficiado de la catedral, a no ser que voluntariamente así lo dispongan los difuntos en sus testamentos. También declara que los obispos, que anteriormente lo hicieran, lo habían efectuado contra derecho ${ }^{126}$.

Sin embargo, colaboraron estrechamente el obispo y su cabildo en la reordenación del culto catedralicio y en la adscripción de nuevas rentas al mismo. De ello aquí sólo destacamos la anexión de los terzuelos de las iglesias «despobladas» a la renta de las distribuciones cotidianas a los beneficiados de la catedral ${ }^{127}$.

124 J. GÓMEZ BRAvo, Catálogo.I, pp. 313 y 315. Véase M. NiETo CUMPLIDO, «Repercusiones del Cisma de Occidente en la diócesis de Córdoba», en B.R.A.C., 98 (1978), p. 53 y notas 25 y 26.

12512 de marzo de 1375. B.C.C., Ms. 166, f. 25.

126 Jaén, 9 de junio de 1374. A.C.C., caj. N, n. 55.

127 «Propterea donamus et assignamus et in perpetuum concedimus vobis, decano et capitulo supradictis, ut habeatis in perpetuum quolibet anno tertiam partem omnium fructuum et reddituum terciarum partium decimarum fabricis depopulatarum ecclesiarum nostre diocesis debitarum que pro nunc sunt et erunt in futurum...». Córdoba, 7 de octubre de 1374. A.C.C., caj. N, n. 61. B.C.C., Ms. 166, ff. 10-11. Esta concesión se había hecho un año antes con estas palabras: «... Damos e en perpetuo otorgamos a vos el deán e cabildo de la dicha eglesia que ayades para syempre cada anno la terçia parte de todo lo que rindieren los terçiuelos de todas las iglesias de este nuestro obispado que agora son e serán de aquí adelante non pobladas para distributiones cothidianas». El texto latino es más preciso. 
Esta es la primera vez que aparece en la documentación cordobesa referencia a despoblados y particularmente a iglesias despobladas, con la particularidad de que se habla en presente y en futuro. Esto parece indicar un cambio de mentalidad en la sociedad cordobesa, pues el concepto de despoblado no se aplica a un lugar desierto de población, sino con poca población en comparación con otros núcleos, admitiéndose como necesario el proceso de concentración de población a favor de unos centros y en perjuicio de otros. Las causas de esta concentración ya se advirtieron en nuestro libro de Geografia del Obispado de Córdoba en la Baja Edad Media. Sólo queda añadir que el fenómeno y su solución en lo tocante a las tercias reales se abordó para las diócesis de Córdoba y Sevilla en 1377, determinando el rey continuar percibiendo sus tercias reales como antiguamente cuando estos núcleos estaban más poblados ${ }^{128}$.

La defensa de las rentas eclesiásticas frente a los abusos de los poderosos y de la voracidad del fisco regio también debió ser constante, como consecuencia de los desórdenes provocados por las contiendas civiles, de lo que sólo señalamos dos ejemplos. En 1375 el vicario general y maestrescuela, don Juan Fernández Pantoja, sentenció que pertenecía de siempre al cabildo catedralicio el diezmo del alguacilazgo de Córdoba, cuyas rentas poseía don Gonzalo Fernández de Córdoba, señor de la Casa de Aguilar, quien acabó consintiendo en ello ${ }^{129}$.

En cuanto al fisco regio, éste pretendió hacerse con tercias reales no ya sólo de las fábricas de las iglesias, sino también de las rentas de los donadíos mayores y menores, que eran privativas de la iglesia catedral, por lo que se habían embargado tales rentas. Ante la reclamación del obispo y cabildo catedralicio cordobeses, el rey Enrique II manda a su tesorero mayor en Andalucía y Murcia, Miguel Ruiz, que desembargue tales rentas en $1377^{130}$.

Según Gómez Bravo, no se llevará a cabo ninguan visita del obispado de Córdoba por parte del obispo de Jaén, don Nicolás de Biedma. Este habría recibido mandato del papa Gregorio XI de hacer tal visita, junto con el dominico Montesino, en el arzobispado de Sevilla y en los obispados de Jaén, Córdoba, Badajoz, Plasencia, Coria y Cáceres y también en los maestrazgos de las órdenes militares. Durante su episcaopado se repartió entre el clero un subsidio en favor del cardenal legado Guido de Bolonia de 125 florines de oro ${ }^{131}$.

En cuanto a sus colaboradores hay que anotar al deán don Antón Martínez y al maestrescuela don Juan Fernández Pantoja, que fue su sucesor, como vica-

128 I. SANZ SANCHO, Geografia del Obispado, pp. 153-159. Córdoba, 29 de agosto de 1377. A.C.C., caj. O, n. 147. A.G.S., Patronato Real, T.I., n. 3.062.

129 Córdoba, 17 de agosto de 1375. A.C.C., caj. P, n. 57.

130 Córdoba, 30 de agosto de 1377. A.C.C., caj. O, n. 146,147 y 149.

131 Aviñón, 8 de junio de 1376. J. Gómez BRAvo, Catálogo.I, pp. 315-316. Toledo, 20 de enero de 1373. A.C.C., caj. H, n. 148. 
rios generales. Según Nieto Cumplido, murió este obispo el día 7 de enero de 1379. En el Libro Verde consta la dotación de oficios de este obispo, así como que fue tío del racionero Pedro Alfonso ${ }^{132}$.

\section{DON JUAN FERNÁNDEZ PANTOJA (31 de enero de 1379 a abril de 1397).}

A los pocos días de la muerte de don Alfonso de Vargas se reunió el cabildo catedralicio de Córdoba para elegir a su sucesor en la sede. La elección recayó, según Gómez Bravo, por unanimidad de los votos, en la persona de don Juan Fernández Pantoja, hasta entonces canónigo y maestrescuela de esta Iglesia ya en 22 de julio de 1371 y varios años vicario general del obispado, desde 17 de agosto de 1375, así como canónigo de Sevilla.

Tal elección debió producirse el 31 de enero de 1379, fecha en la que los electores comisionan a los canónigos Juan Ruiz y Antonio García de Santa Marina para que informen al papa de Roma, Urbano VI, sobre el resultado de su elección y recaben su confirmación ${ }^{133}$.

Cabe pensar que el cabildo catedralicio desconociera que los dos pontifices, con los que contaba la Iglesia desde el 20 de septiembre de 1378, el ya dicho Urbano VI y el aviñonés Clemente VII, se habían reservado la provisión de la sede cordobesa. Pero también cabe imaginar que el mismo cabildo, conocedor de la postura neutral del rey Enrique II sobre el reconocimiento de cualquiera de los dos papas desde noviembre de 1378 y deseoso de evitar las consecuencias de una larga vacante a causa de un conflicto, que se preveía duradero y a resolver fuera del área de influencia de los propios capitulares, decidiera actuar con la máxima celeridad. Procedería, pues, el cabildo a una rápida elección y, como mal menor, después esperar a las oportunas confirmaciones y consagración. En principio, esperar la confirmación del que hasta entonces al menos era reconocido papa, Urbano VI.

La generalidad de la Iglesia de Córdoba dio por válida e incuestionable tal elección episcopal y mantuvo en todo momento la obediencia sin discusión a su obispo electo. Este actuó desde el principio con plenitud de poderes jurisdiccionales y sin hipoteca alguna, que se derivase del Cisma de Occidente, sin duda favorecido el ambiente de normalidad por el apresamiento en Fondi del designado para obispo de Córdoba y legado papal de Urbano VI a Castilla y Aragón, fray Menendo, franciscano.

El obispo electo y además representante del cabildo catedralicio cordobés, don Juan Fernández, consigue en las Cortes de Burgos, 15 de agosto de 1379,

132 B.C.C., Libro Verde, f. 92.

133 A.C.C., caj. M, n. 49. 
la confirmación de los privilegios de su Iglesia por el recientemente jurado rey Juan I ${ }^{134}$. Acude como electo y confirmado por el metropolitano de Toledo, don Pedro Tenorio, a varias asambleas del clero de Castilla para tratar sobre el asunto de dar la obediencia o reconocer a uno de los dos papas. Incluso debió encontrarse con su teórico rival en cuanto a la sede cordobesa, fr. Menendo, en la asamblea de Medina del Campo en 23 de noviembre de 1380, a la que éste acudió, tras lograr escapar de la prisión, como legado de Urbano VI ${ }^{135}$.

Por su parte, también Clemente VII de Aviñón se había reservado la designación de la sede de Córdoba, aunque no parece que llegara a nombrar a nadie como obispo de la misma. Finalmente, con la aceptación por el rey Juan I del papa aviñonés como legítimo en Salamanca, 18 de mayo de 1381, el cardenal legado de Clemente VII, don Pedro de Luna, nombrará obispo electo de Córdoba al que ya había sido elegido por el cabildo catedralicio y aún confirmado por el metropolitano de Toledo, don Juan Fernández Pantoja, después de declarar nulas ambas actuaciones, pero absolviéndoles de culpa por ignorancia. Poco después el mismo cardenal legado concede al arzobispo de Toledo, don Pedro Tenorio, poder consagrar al electo de Córdoba, lo que efectuará en la catedral de Segovia el 28 de julio de $1381^{136}$. En todo ello hay que ver la vinculación del obispo de Córdoba a la oligarquía de Toledo y a su arzobispo, además de ser ambos defensores del papa aviñonés.

El obispo don Juan era hijo del caballero toledano Martín Fernández Pantoja y de Mayor Gutiérrez Palomeque, además de deudo del arzobispo de Sevilla, fray Alfonso de Vargas, también toledano, fraile agustino y seguramente quien le procurara la canonjía de Sevilla ${ }^{137}$. Además, nuestro obispo electo era subcolector de las rentas de la cámara apostólica en 19 de julio de 1380, cuando se concede en expectativa la canonjía de Sevilla, que quedará vacante por la promoción de don Juan Fernández, al racionero de Salamanca, Juan Alfonso ${ }^{138}$.

Su ascendiente social y eclesiástico le permitió actuar como juez árbitro a petición del concejo de Córdoba para la ejecución de ciertas mandas testamentarias del que fue alguacil mayor de Córdoba, Fernando Alfonso ${ }^{139}$.

${ }^{134}$ A.C.C., caj. M, n. 16. B.N., Ms. 13.077, f. 66. R.A.H., Ms. 9/5.436, f. 522.

135 Un resumen de las implicaciones del Cisma de Occidente en la designación para ocupar la vacante sede de Córdoba puede verse en M. NIETO CUMPLIDO, «Repercusiones del Cisma de Occidente en la Diócesis de Córdoba, en B.R.A.C., 98 (1798), pp. 47-73. Otras noticias sobre fray Menendo en EUBEL, C.: Hierarchia.I, p. 209. J. GÓMEZ BRAvo, Catálogo.I, pp. 316-319.

136 Salamanca, 25 de mayo de 1381. A.C.C., caj. M, n. 48. J. Gómez Bravo, Catálogo.I, p. 319. Concesión de la facultad para consagrar en Valladolid, 15 de julio de 1381. Testimonio notarial de la consagración en Segovia, 28 de julio de 1381. A.C.C., caj. M, n. 52.

137 B.C.C., Libro Verde, f. 115.

138 V. BELTRÁN DE HEREDIA, Bulario, pp. 430-431.

139 Este había mandado reparar el puente del Guadalbarbo, en la localidad de Puente de Alcolea, a cargo de ciertos bienes, que legaba para ello, entre otros la heredad de Villalovillos. Sus herederos, al partir 
Este mismo año, en 1 de junio, también actuó como juez árbitro, junto con el alcalde mayor de Córdoba, don Lope Gutiérrez, en la disputa, que enfrentaba a don Miguel Ruiz, tesorero mayor de Andalucía, con el cabildo catedralicio sobre el diezmo a pagar por aquél por su tenencia de la casa del jabón de Córdoba. En la sentencia arbitral se reconoce el derecho decimal del cabildo y se fija una cantidad por los años en los que no lo había pagado ${ }^{140}$. Otras actuaciones, ya más propiamente pastorales, realizó en 1385, al crear la iglesia parroquial de Fernán Núñez y al dispensar del impedimento de parentesco para el matrimonio a Diego Gutiérrez de los Ríos y María de Palma ${ }^{141}$.

Las buenas relaciones del obispo con su cabildo catedralicio se mostraron fructíferas para ambos. Ya se vio que, cuando era obispo electo, fue a la vez delegado del cabildo ante la corte real. Al poco de su vuelta a la diócesis como obispo consagrado inició una visita al obispado, de la que queda constancia en un estatuto capitular de 1382, al igual que de la efectuada en $1388^{142}$.

Estas buenas relaciones se muestran en las donaciones pro anima, que hizo el obispo en 1391 y en su testamento de 31 de marzo de $1397^{143}$. Por su parte, el cabildo le condonó $850 \mathrm{mrs}$. de la deuda que con la mesa capitular tenía el obispo en 1392 por las casas que tenía el obispo y su obligación con ciertas fiestas y aniversarios dotados ${ }^{144}$. Esta cooperación dio frutos abundantes de estatutos capitulares conservados.

\footnotetext{
la hacienda, habían dado esta heredad a su sucesor, don Diego Fernández alcaide de los Donceles, para que la vendiera y sufragara los gastos de construcción del puente. Pero éste no llegó a realizarlo, sino que se apropió de la heredad y de su renta. Finalmente, en su testamento repitió la manda de su padre, añadiendo a tal fin otra heredad que compró, llamada la Bastida, más $7.000 \mathrm{mrs}$., en concepto de indemnización por no haber ejecutado el testamento paterno, cuya obra y ejecución encargó a su hermano, don Gonzalo Fernández, como albacea junto a su hijo don Martín Fernández, alcaide de los Donceles.

Como a estos albaceas se les pasara el tiempo legal para hacer ejecución del testamento y no habían llevado a efecto ni la obra ni la venta de los bienes mandados para la misma, acudieron al obispo para que éste designase «marmesores», que lo cumpliesen. Así lo hizo en las personas de Ruy Fernández y Pedro Lorenzo Savariego, «veinticuatros» del concejo. Examinada la cuestión por el concejo, se vio que ambas heredades, más los $7.000 \mathrm{mrs}$, no bastaban para labrar el puente, cuya obra, sin embargo, era imprescindible. Por ello pide el concejo al obispo que mande entregar tales bienes al concejo y que se destinen a propios del mismo. A cambio de lo cual, el concejo se compromete a ejecutar a su costa tal obra. Lo cual concedió nuestro obispo con fecha de Córdoba, 17 de abril de 1383. A.C.C., caj. M, n. 134. R.A.H., Ms.. 9/5.434, ff. 94-97.

140 Córdoba, 1 de junio de 1383. A.C.C., caj. P, n. 99.

141 Castronovo, 13 de septiembre de 1385. A.V., Reg. Vat. 296, f. 163. J. GómEZ BRAVo, Catálogo.I, p. 323.

1427 de julio de 1382. B.C.C., Ms. 166, f. 58. 21 de octubre de 1388. J. GómEZ BrAvo, Catálogo.I, p. 320.

14321 de octubre de 1391. J. Gómez Bravo, Catálogo.I, p. 324. R. RAMíreZ DE ARELLANO, Historia de Córdoba.IV, p. 142. El testamento en A.C.C., caj. T, ns. 317 y 318. R. FERNÁNDEZ GONZÁLEZ, «El castillo de Toledillo», en B.R.A.C., 96 (1976), pp. 5-56.

14428 de agosto de 1392. A.C.C., caj. I, n. 395.
}

Episcopado Hispano

Hispania Sacra 54 (2002) 
Hemos anotado dos visitas pastorales durante su episcopado, a las que le acompañaron algunos miembros del cabildo catedralicio, en 1382 y en 1388. En cuanto a sus colaboradores más cercanos citamos al chantre don Juan Fernández de Frías, bachiller en decretos y lector por 2 años en Salamanca y por 3 años en Córdoba de derecho canónico, que es admitido a examen de licencia de doctorado en Salamanca en 1386.

También durante su episcopado el clero hubo de pagar varias sumas. Un subsidio para la Cámara Apostólica impuesto por el papa Clemente VII, que asecendía a 550 doblas de oro. Un pecho al rey Juan I, aprobado en las cortes de Valladolid de noviembre de 1385, en el cual tocó pagar al cabildo catedralicio 39.508 mrs. ${ }^{145}$

Según Gómez Bravo, murió en abril de 1397. El cabildo catedralicio hizo una ordenación, por la que los beneficiados asistentes a los oficios y aniversarios de nuestro obispo ganaran $100 \mathrm{mrs}$. en la vigilia y $100 \mathrm{mrs}$. en la misa y se celebraran con cuatro capas negras, ya en 21 de septiembre de $1397^{146}$.

\footnotetext{
145 Aviñón, 5 de diciembre de 1384. A.C.C., caj. H, n. 158. Valladolid, 22 de diciembre de 1385. A.C.C., caj. H, n. 105. Córdoba, 6 de marzo de 1387. A.C.C., caj. I, n. 396.

146 B.C.C., Ms. 166, f. 56. A.C.C., caj. L, n. 135.
}

Episcopado Hispano Hispania Sacra 54 (2002) 